\author{
UNIVERSITY OF MINNESOTA \\ ST. ANTHONY FALLS HYDRAULIC LABORATORY \\ LORENZ G. STRAUB, Director
}

Technical Paper No. 15, Series B

\title{
Straight Drop Spillway Stilling Basin
}

by

Charles A. Donnelly and Fred W. Blaisdell

Hydraulic Engineers, USDA, ARS

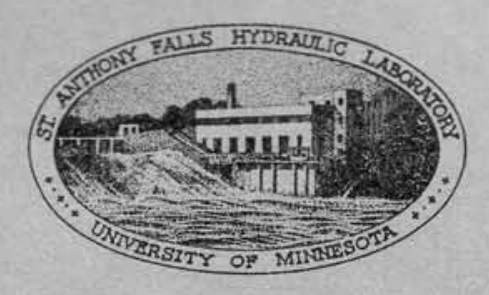

November, 1954

\begin{abstract}
Study conducted by
UNITED STATES DEPARTMENT OF AGRICULTURE

AGRICULTURAL RESEARCH SERVICE

SOIL AND WATER CONSERVATION RESEARCH BRANCH
\end{abstract}

in cooperation with the

Minnesota Agricultural Experiment Station

and the

St. Anthony Falls Hydraulic Laboratory 


\author{
UNIVERSITY OF MINNESOTA \\ ST. ANTHONY FALLS HYDRAULIC LABORATORY \\ LORENZ G. STRAUB, Director
}

Technical Paper No. 15, Series B

\title{
Straight Drop Spillway Stilling Basin \\ by
}

Charles A. Donnelly and Fred W. Blaisdell

Hydraulic Engineers, USDA, ARS

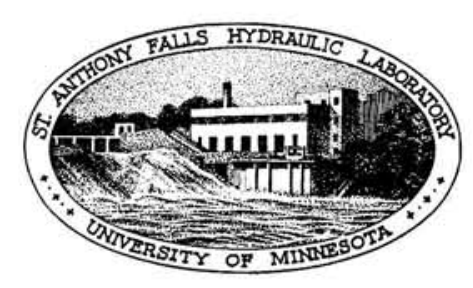

November, 1954

Study conducted by

UNITED STATES DEPARTMENT OF AGRICULTURE

AGRICULTURAL RESEARCH SERVICE

SOIL AND WATER CONSERVATION RESEARCH BRANCH

in cooperation with the

Minnesota Agricultural Experiment Station

and the

St. Anthony Falls Hydraulic Laboratory 


\section{$\underline{A} \underline{B} \underline{S} \underline{T} \underline{R} \underline{A} \underline{\mathrm{C}} \underline{T}$}

This paper describes the development of the generalized design rules for a new stilling basin for use with the straight drop spillway. This generalized stilling basin design was developed because experience in the field had shown that there was no satisfactory stilling basin for the straight drop spillway. However, linited field experience indicates that this new design will adequately protect the downstream channel from scour.

Water falling over the spillway crest falls onto a flat apron. The nappe is broken up by floor blocks, which also prevent damaging scour of the downstream channel banks. Scour of the downstream channel bed is prevented by an end sill. Flaring wingwalis, triangular in elevation, prevent erosion of the dam fill. For proper operation of the stilling basin, the contraction of the flow at the ends of the spillway opening must be partially suppressed.

The stilling basin can be used for a wide range of discharge, head on the crest, crest length, height of drop, and downstream tailwater level.

An important finding is that the stilling basin length computed for the minimum tailwater level required for good performance may be inadequate at higher tailwater levels. Dangerous scour of the downstream channel may occur if the nappe is supported sufficiently by high tailwater so that it lands beyond the end of the stilling basin. A method of computing the stilling basin length for all tailwater levels is presented.

The design rules developed as a result of the laboratory tests were carefully checked and verified. An example shows how these rules are applied to the design of a field structure. 
Abstract ...................... ... ii

List of Illustrations ................ . v v

List of Tables...................... V V

list of Symbols ................... . . . vi

Frontispiece..................... . . . viii

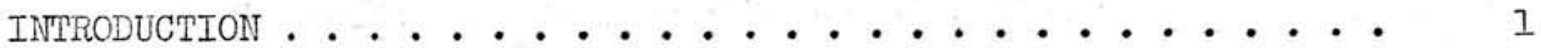

PREVIOUS TORK . . . . . . . . . . . . . . . 2

APPARATUS AND PROCEDURE . . . . . . . . . . . . . 3

TEST RESULTS ........................ 5

Length of Basin...................

Nappe Trajectory ................. . . . 5

Distance to Floor Blocks ............ 10

Distance to End Sill . . . . . . ..... 12

Tailwater Depth................ . . . . 13

Floor Block and End Sill Height . . . . . . . . . 17

Floor Block Width and Spacing .. . . . . . . . . 19

Sidewall Height . . . . . . . . . . . . . 23

Wingwalls .................. . . . . . 24

Approach Channel .................. . . . . 24

Aeration Under Nappe .............. . . . . 25

Check Tests................. 26

SUIMLARY . . . . . . . . . . . . . . . . 27

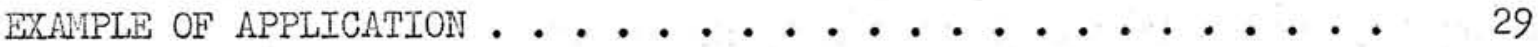

Bibliography . . . . . . . . . . . . . 35 


$$
\underline{I} \underline{I} \underline{T} \quad \underline{O} \underline{F} \quad \underline{I} \underline{L} \underline{L} \underline{U} \underline{S} \underline{T} \underline{R} \underline{A} \underline{T} \underline{I} \underline{O} \underline{N} \underline{S}
$$

Figure

1 Test Apparatus .................

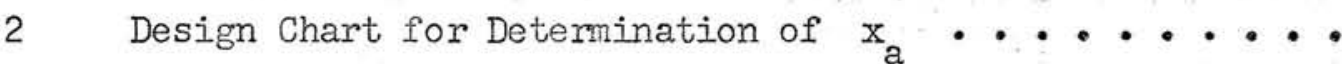

3 The Bed Scour Is Deeper than Necessary and the Bank Scour Is Excessive Because of Improper Location or Absence of the Floor Blocks ............

4 Floor Blocks Located $0.8 \mathrm{~d}_{\mathrm{c}}$ from the Point Where the Nappe Strikes the Basin Floor and $1.75 \mathrm{~d}_{\mathrm{c}}$ from the End of the Stilling Basin Give Maximum Protection to the Bed and Banks ...............

5 Floor Blocks Located $0.75 \mathrm{~d}_{\mathrm{c}}$ from the End of the Stilling Basin Are Ineffective; the Bed Scour is Deeper than Necessary, and the Bank Scour is Excessive ........................ 13

6 Determination of Tailwater Depth . . . . . . . 15

7 Effect of Tailwater Ievel on Downstream Scour . . . . I6

8 Scour Near End of Stilling Basin . . . . . . . 16

9 Effect of Proportion of Basin Width Occupied by Floor Blocks on Scour of Bed and Banks ........ 22

10 Straight Drop Spillway Stilling Basin . . . . . . 28

11 Example of Straight Drop Spillway Stilling Basin Designed for High Tailwater . . . . . . . . . 32

12 Example of Straight Drop Spillway Stilling Basin Designed for Normal Tailwater ... . . . . . . .

\section{$\underline{I} \underline{I} \underline{T} \quad \underline{O} \underline{F} \quad \underline{T} \underline{A} \underline{B} \underline{L} \underline{E} \underline{S}$}

Table

No.

I Floor Block and End Sill Height . . . . . . . .

II Floor Block Width and Spacing . . . . . . . . . 


\section{$\underline{I} \underline{I} \underline{S} \underline{O} \quad \underline{F} \quad \underline{S} \underline{Y} \underline{M} \underline{B} \underline{O} \underline{\underline{L}} \underline{S}$}

$d_{2}$ distance from téilwater'surface to floor of stilling basin

$d_{c} \quad$ critical depth $=\sqrt[3]{(0 / \mathrm{L})^{2} / \delta}=(2 / 3) \mathrm{H}$

\& acceleration due to gravity

H specific head in approach to crest $=$ depth plus velocity head $=(3 / 2) d_{c}$

I $\quad$ crest length $=$ stilling basin width

$I_{B}$ minimum stilling basin length $=x_{0}+x_{b}+x_{c}$

Q discharge

$v_{c}$ critical velocity

$\mathrm{x}_{\mathrm{F}}$ horizontal distance from crest to point where upper surface of freefalling nappe strikes stilling basin floor

$\mathrm{x}_{\mathrm{a}}$ horizontal distance from crest to point at which average of upper surfaces of free-falling and tangent nappes strikes stilling basin floor $=\left(x_{F}+x_{\eta}\right) / 2$

$x_{b}$ distance to floor blocks from point at which average of upper surfaces of free-falling and tangent nappes strikes stilling basin floor

$x_{c}$ distance from upstrean face of floor blocks to end of stilling basin $x_{n}$ horizontal distance from crest to upper surface of free-falling nappe $x_{n s}$ horizontal distance from crest to upper surface of submerged nappe

$x_{t}$ horizontal distance from crest to point at which upper surface of freefalling nappe plunges into tailwater

$\mathrm{x}_{\mathrm{T}}$ horizontal distance from crest to point where upper surface of tangent nappe strikes stilling basin floor

y vertical distance from crest to stilling basin floor ( $y$ is negative)

$y_{n} \quad$ vertical distance from crest to upper surface of free-falling nappe $\left(y_{n}\right.$ is positive above the crest and negative below the crest)

$J_{t}$ vertical distance from crest to tailwater surface ( $y_{t}$ is positive when the tailwater surface is above the crest, negative when the tailwater surface is below the crest) 


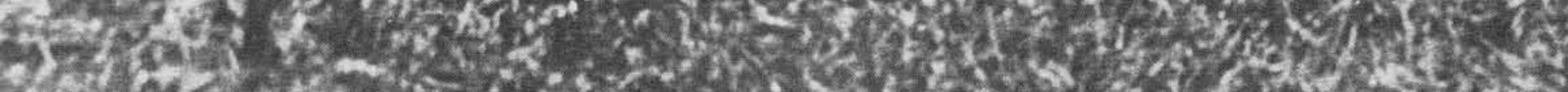

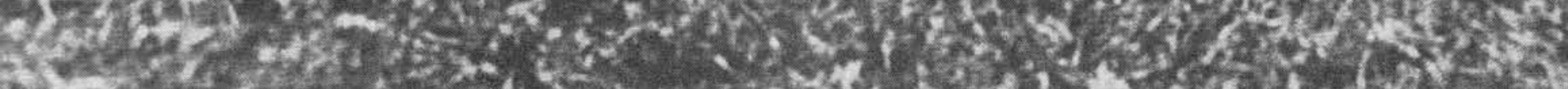

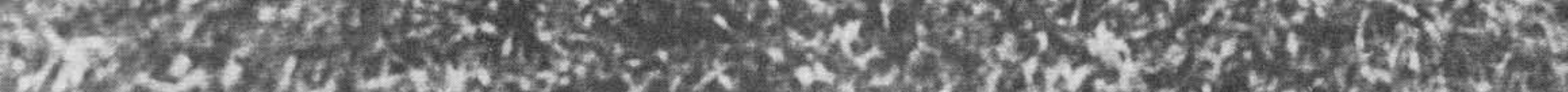

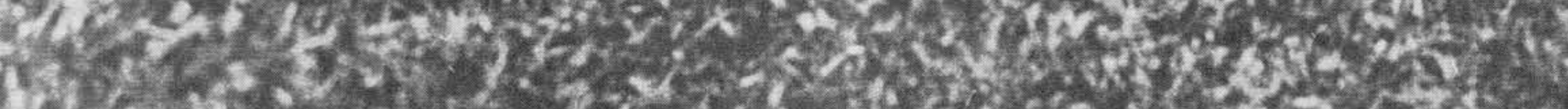

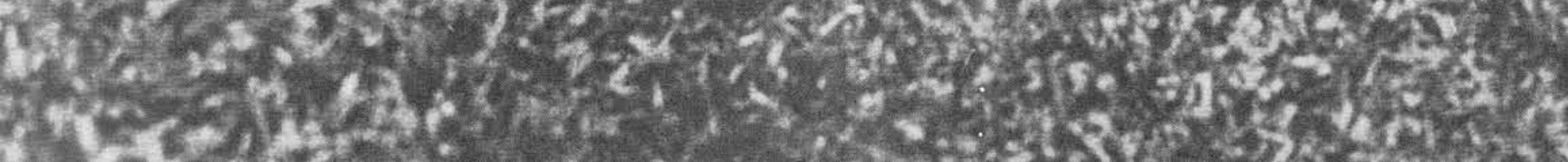

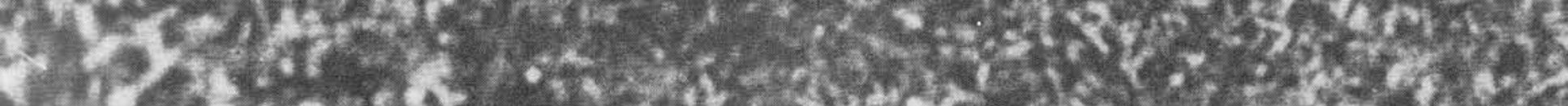

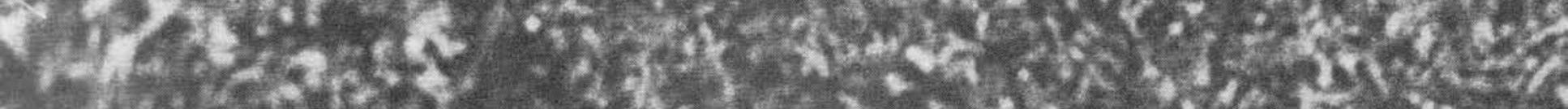

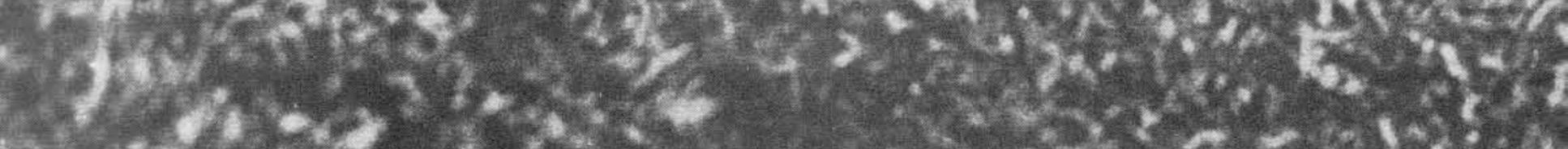




\section{STRAIGHT DROP SPILLINAY STILLING BASIN *}

\section{INTRODUCTION}

The straight drop spillway is, just as the name implies, a straight overfall weir. The water flowing over the spillway falls onto a horizontal apron. The energy in the water is dissipated by means of blocks, sills, and tailwater. The water is discharged from the stilling basin into the downstream channel in such a manner as to prevent damaging scour.

The straight drop spillway is used as an erosion control structure in gullies, as a grade control structure in drainage ditches, as an irrigation drop and check stmucture, and as a spillway for earth dans.

A generalized design for a straight drop spillway stilling basin was developed as a result of the tests described in this paper. The design is applicable to relative heights of fall ranging from $1.0 \mathrm{y} / \mathrm{d}_{\mathrm{c}}$ to $15 \mathrm{y} / \mathrm{d}_{\mathrm{c}}$ and to crest lengths greater than $1.5 \mathrm{~d}_{\mathrm{c}}$. Here $\mathrm{y}$ is the vertical distance between the crest and the stilling basin floor, and $d_{c}$ is the critical depth of flow.

This experimental investigation was begun early in 1951 at the request of the Engineering Council of the Soil Conservation Service, U. S. Department of Agriculture. It was completed late in 1953. The study was made by the staff of the Agricultural Research Service** located at the St. Anthony Falls Fydralic Laboratory, University of Minnesota, Minneapolis. There the Agricultural Research Service, the Minnesota Agricultural Experiment Station, and the St. Anthony Fals Hydraulic Laboratory cooperate in the solution of problems concerning conservation hydraulics. The studies which are being conducted by the Agricultural Research Service at the St. Anthony Falls Hydraulic Laboratory of the University of Minnesota are administered by the Watershed Hydrology Section of the Soil and Water Conservation Research Branch. The testing and much of the analysis was done by Charles A. Donnelly, Hydraulic Engineer, Agricultural Research

*Agricultural Research Service Report No. 41-504-52.

**The studies at the St. Anthony Falls Hydraulic Iaboratory, initiated by Soil Conservation Service - Research on January 1, 1940, were transferred to Agricultural Research Service on January 1, 1954. 


\section{STRAIGHT DROP SPILLWAY STILIING BASIN *}

\section{INTRODUCTION}

The straight drop spillway is, just as the name implies, a straight overfall weir. The water flowing over the spillway falls onto a horizontal apron. The energy in the water is dissipated by means of blocks, sills, and tailwater. The water is discharged from the stilling basin into the downstream channel in such a manner as to prevent damaging scour.

The straight drop spillway is used as an erosion control structure in gullies, as a grade control structure in drainage ditches, as an irrigation drop and check structure, and as a spillway for earth dams.

A generalized design for a straight drop spillway stilling basin was developed as a result of the tests described in this paper. The design is applicable to relative heights of $\mathrm{fall}$ ranging from $1.0 \mathrm{y} / \mathrm{d}_{\mathrm{c}}$ to $15 \mathrm{y} / \mathrm{d}_{\mathrm{c}}$ and to crest lengths greater than $1.5 \mathrm{~d}_{\mathrm{c}} \cdot$ Here $\mathrm{y}$ is the vertical distance between the crest and the stilling basin floor, and $d_{c}$ is the critical depth of flow.

This experimental investigation was begun early in 1951 at the request of the Engineering Council of the Soil Conservation Service, U. S. Department of Agriculture. It was completed late in 1953. The study was made by the staff of the Agricultural Research Service ${ }^{* *}$ located at the St. Anthony Falls Hydraulic Laboratory, University of Minnesota, Minneapolis. There the Agricultural Research Service, the Minnesota Agricultural Experiment Station, and the St. Anthony Falls Fydraulic Laboratory cooperate in the solution of problems concerning conservation hydraulics. The studies which are being conducted by the Agricultural Research Service at the St. Anthony Falls Hydraulic Laboratory of the University of Minnesota are administered by the Watershed Hydrology Section of the Soil and Water Conservation Research Branch. The testing and much of the analysis was done by Charles A. Donnelly, Hydraulic Engineer, Agricultural Research

\footnotetext{
*Agricultural Research Service Report No. 41-504-52.
}

**The studies at the St. Anthony Falls Hydraulic Laboratory, initiated by Soil Conservation Service - Research on January 1, 1940, were transferred to Agricultural Research Service on January 1, 1954 . 
Service. This paper was compiled by him and Fred W. Blaisdell, Project Supervisor, who is also responsible for the nappe trajectory analysis. The technical content and presentation of the paper have been critically reviewed by Dr. Alvin G. Anderson, Assistant Professor of Hydraulics, St. Anthony Falls Hyòraulic Iaboratory, and Mr. M. M. Culp, Head, Design Section, Ingineering Division, Soil Conservation Service. Editorial preparation was with the assistance of the Laboratory staff. The thanks of the authors go to all who have so generously contributed constructive comments.

This report is broken down into a number of sections. Introductory sections describe previous work, the test program, and the apparatus and procedure used in conducting the tests. The results of the tests are sumarized in the form of design rules and equations.

\section{PREVIOUS WORK}

Excessive scour at the outlet of a number of straight drop spillways located at the Whiting Field Naval Auxiliary Air Station, Milton, Florida, resulted in a request for model studies of this outlet and for recommendation of a better outlet design. The Whiting Field structures had been designed according to the criteria presented in the paper entitled "Hydraulic Design of Drop Structures for Gully Control" [1]*. Model studies conducted in 1948 with a downstream channel formed of sand verified the excessive scour observed at Whiting Field [2].

A series of tests was conducted in 1950 using the outlet design mentioned in the previous paragraph to see if wingwalls triangular in elevation would reduce the scour. Triangular wingwalls had previously been found effective in controlling bank scour [3, 4]. These tests were sponsored by Region III of the Soil Conservation Service. They showed that while the bank scour was reduced through the use of the triangular wingwalls, not enough energy was dissipated in the outlet to reduce the bed scour to a tolerable amount.

A satisfactory stilling basin incorporating floor blocks and an end sill was developed through model studies for use at Whiting Field [2]. Subsequent experience at Whiting Field has shown the complete absence of scour in the channel downstream from this stilling basin and has verified the laboratory studies. The instmuctions from the Engineering Council were to develop generalized design mies for this stilling basin.

\footnotetext{
* Nurnbers in brackets refer to bibliography listed on Page 35.
} 


\section{APPARATUS AND PROCEDURE}

The test apparatus is shown in Fig. I The water for the experiments was obtained from a constant-level tank installed in the Laboratory main supply channel. Water entered the constant-level tank through a 12in. butterfly valve which was hydraulically operated from the main floor. The exit was through a 6-in. pipe. The quantity of water was controlled by a 6-in. gate valve, discharged into a stilling pool, and passed under a solid baffle which serves to quiet and distribute the flow before it goes to the 1.0-ft type $\mathrm{H}$-flume which was used for measuring the quantity of water.

Water from the $\mathrm{H}$-flume drops into a stilling pool and passes under a solid baffle which serves to quiet and distribute the flow in the 6-ft wide, 10-ft long, and 2-ft deep approach channel. The approach channel was made of steel stair stringer channels bolted together. For most of the tests, the approach to the crest was a concrete channel level with the

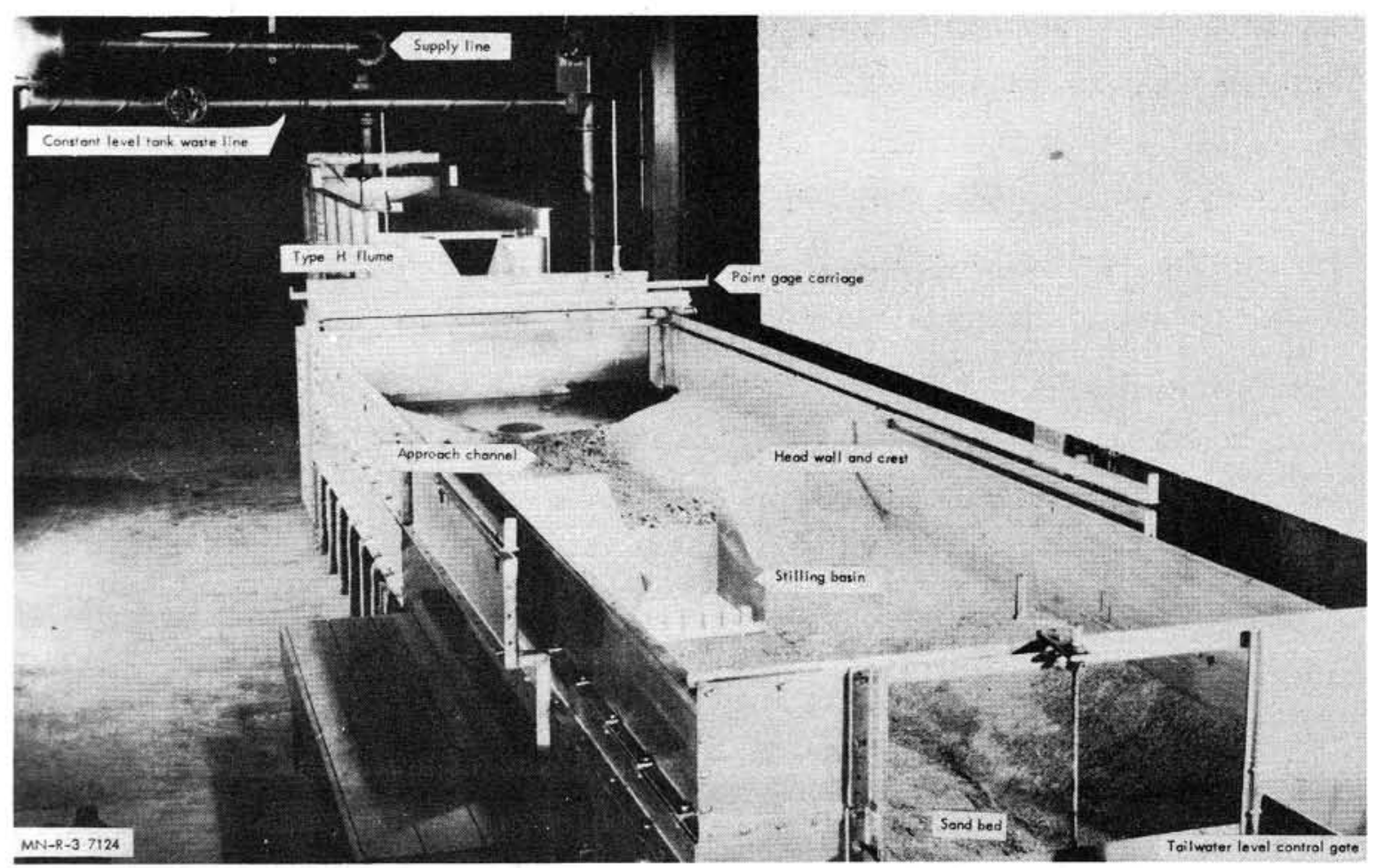

Fig. 1 - Test Apparatus 
crest and equal to the crest length in bottom width. The concrete channel sides had a 1 on 2 slope. The outlet channel was $5 \mathrm{ft}$ wide, $10 \mathrm{ft} \mathrm{long,}$ and $2.5 \mathrm{ft}$ deep. The headwall between the two channels was provided with an opening for insertion of the models. An adjustable gate at the downstream end of the exit channel controls the tailwater level.

A point gage was attached to a carriage which ran on rollers along the top of the channel in such a manner that levels anywhere in the approach channel and in the test section could be readily obtained. This gage was used in setting the models to the correct elevation and in determining the levels of the water surface and the sand bed. The models were made of plywood and white pine. With the use of lumber, changes were made with very little effort. Ordinary concrete sand passing an 8-mesh screen was used for the stream bed downstream from the spillway. The erosion of the sand bed was used as a measure of the efficiency of the outlet.

In each experiment, a stilling basin was installed and the stream bed was filled with sand to an elevation above the top of the end sill. The bank slope was approximately 1 on 2. The stream bed was flooded so that the initial rush of water through the stilling basin would not erode the stream bed excessively. The gate valve in the supply line was then opened to give the desired discharge, and the tailwater level was adjusted to give the correct depth. A flow photograph was taken during the test. After the water had mun through the model for two hours, the valve was closed and the water allowed to drain. The water level in the outlet was measured at intervals during the drainage process by means of the point gage. Zero elevation was assumed to be the elevation of the top of the end sill. White wool yarn was placed on the water line at l-in. intervals to define the contours. The contbured bed was photographed to record the scour.

The data obtained during each test consisted of the structure dimensions, flow data, notes, and photographs. The photographs provided the principal means of recording and analyzing the performance of the structure. Since only one feature of the stilling basin was changed for each test, the photographs provided a recorc of the effect of each change and served to define the optimum dimensions. 


\section{TEST RESULTS}

The results of the tests made to determine the dimensions of the straight drop spillway stilling basinwill be presented separately for each element comprising the basin. The order of presentation is not the order in which the tests were conducted. In fact, it was necessary to study some elements several times because a change in one element would affect the performance of other elements, and the best result could only be obtained after each element had its optimum dimensions.

\section{Iength of Basin}

It was recognized before the tests were begun that the point at which the nappe hit the stilling basin floor would provide one of the dimensions for the determination of the basin length. Other dirnensions detemining the basin length are the distance from the nappe to the floor blocks and the distance from the floor blocks to the end of the basin. Each of these dimensions will be discussed in turm.

\section{Nappe Trajectory}

The equation first used during these studies to give the trajectory of the upper surface of the free-falling nappe is

$$
\frac{y_{n}}{H}=0.46-0.105\left[3\left(\frac{x_{n}}{H}\right)+2\left(\frac{x_{n}}{H}\right)\right]
$$

where $y_{n}$ is the vertical distance, $x_{n}$ is the horizontal distance from the crest to the upper surface of the nappe, and $H$ is the total head. This equation was derived from data presented by Dr. A. T. Ippen [5] for the free overiall, since the straight drop spillway is assumed to have the approach channel level with the spillway crest.

This equation proved satisfactory until tests were run with the tailwater level close to the spillway crest. For these tests the nappe did not fall freely but was supported by the high tailvater. The result was that the nappe hit the stream bed downstrean of the stilling basin and 
scoured a deep hole there. The fact that greater scour was obtained with a higher tailwater level had an important effect on the stilling basin design. Although this discovery is contrary to the widely held opinion that higher tailwater will cause less scour to occur, it is an entirely logical finding. The water in the free-falling nappe is assumed to have a constant horizontal velocity and a vertical velocity accelerating under the effect of gravity. After the free-falling nappe plunges into the tailwater, gravity is no longer effective and the submerged nappe will continue in the direction the free-falling nappe was traveling when it entered the tailwater. Near the crest the upper surface of the free-falling nappe trajectory has a relatively flat slope, and if the tailwater level is also close to the crest, the submerged nappe will contimue on this flat slope. The result is, of course, that the submerged nappe trajectory is well downstream of the free-falling nappe trajectory when the tailwater level is high.

One qualification to the statement regarding the plunging nappe should be made. When the tailwater level is considerably above the crest of the spillway, the nappe does not plunge through the tailwater but "floats" on or close to the surface of the tailwater. For this condition, the nappe does not attack the bed downstream from the stilling basin. During the tests it was noticed that the "surface nappe" occurred when the depth of the tailwater above the spillway crest level exceeded two-thirds the critical depth approximately. Therefore, it is concluded that the effect of high tailwater levels on the position of the nappe need not be considered in the determination of the stilling basin length when the tailwater level exceeds the spillway crest elevation plus two-thirds the critical depth, but the effect of tailwater on the nappe trajectory must be considered for tailwater elevations lower than the spillway crest elevation plus two-thirds the critical depth. In other words, the maximum tailwater level that will affect the stilling basin length is that level which is two-thirds the critical depth above the spillway crest level.

After discovering that the tailwater level influenced the nappe trajectory, tests were made considering that the nappe is free-falling to the tailwater level and continues on a tangent beyond that point. These tests resulted in considerably longer basins when the tailwater was high. In fact, the experiments showed that the basins were longer than necessary 
so they were shortened successively until they were so short that their performance became poor. As a result of these tests, the optimum trajectory of the upper nappe surface for use in determining one of the elements making up the basin length was found to be midway between the free-falling and the submerged trajectories.

This mean trajectory was used for all subsequent tests and was found to give entirely satisfactory results. It is proposed only for use in determining the length of the straight drop spillway stilling basin and should not be used for other purposes until it is confirmed for such use.

The equation of the upper surface of the Iree-falling nappe proposed for use is

$$
\frac{x_{n}}{d_{c}}=-0.406+\sqrt{3.195-4.386 \frac{y_{n}}{d_{c}}}
$$

This equation is a rearrangement and a substitution of $3 \mathrm{~d}_{\mathrm{c}} / 2$ for $\mathrm{H}$ in the general equation for free-falling nappes presented by Blaisdell [6]. It applies to the free overfall only.

At the point where the upper surface of the free-falling nappe strikes the stilling basin floor, Eq. (I) becomes

$$
\frac{x_{F}}{d_{c}}=-0.406+\sqrt{3.195-4.368 \frac{y}{d_{c}}}
$$

where $x_{F}$ is the horizontal distance from the crest to the upper surface of the free-falling nappe at the elevation of the stilling basin floor.

The equation for the upper surface of the submerged nappe trajectory above the tailwater level is the same as that for the free-falling nappe. The point at which the upper nappe plunges into the tailwater is

$$
\frac{x_{t}}{d_{c}}=-0.406+\sqrt{3.195-4.386 \frac{y_{t}}{d_{c}}}
$$

where $x_{t}$ is the horizontal distance from the crest to the point at which the surface of the upper nappe plunges into the tailwater and $y_{t}$ is the 
vertical distance from the crest to the tailwater surface. It is necessary to keep the signs correct, remembering that $\mathrm{y}_{t}$ is positive above crest elevation and negative below. This is illustrated in the definition sketch of Fig. 2. The equation of the trajectory of the upper nappe surface below tailwater level is

$$
\frac{x_{n s}}{d_{c}}=\frac{0.691+0.228\left(x_{t} / d_{c}\right)^{2}-\left(y_{n} / d_{c}\right)}{0.185+0.456\left(x_{t} / d_{c}\right)}
$$

where $x_{n s}$ is the horizontal distance from the crest to the upper surface of the submerged nappe. Equation (4) was obtained by considering that the portion of the nappe trajectory above the tailwater level has the same equation as does the free nappe trajectory, while below the tailwater level the nappe trajectory has a slope equal to

$$
\frac{d\left(y_{t} / d_{c}\right)}{d\left(x_{t} / d_{c}\right)}=-0.185-0.456 \frac{x_{t}}{d_{c}}
$$

Equation (5) can be obtained by rearranging and differentiating Eq. (3). At the point where the upper surface of the submerged nappe trajectory strikes the stilling basin floor, Eq. (4) becomes

$$
\frac{x_{T}}{d_{c}}=\frac{0.691+0.228\left(x_{t} / d_{c}\right)^{2}-\left(y / d_{c}\right)}{0.185+0.456\left(x_{t} / d_{c}\right)}
$$

The distance from the crest at which the average of the upper surfaces of the free and submerged nappes strikes the floor $x_{a}$ is used to determine part of the stilling basin length. The equation for $x_{a}$ is

$$
x_{a}=\frac{x_{F}+x_{T}}{2}
$$

Values of $x_{a}$ have been computed for $a$ wide range of conditions. These results are presented graphically in Fig. 2. 


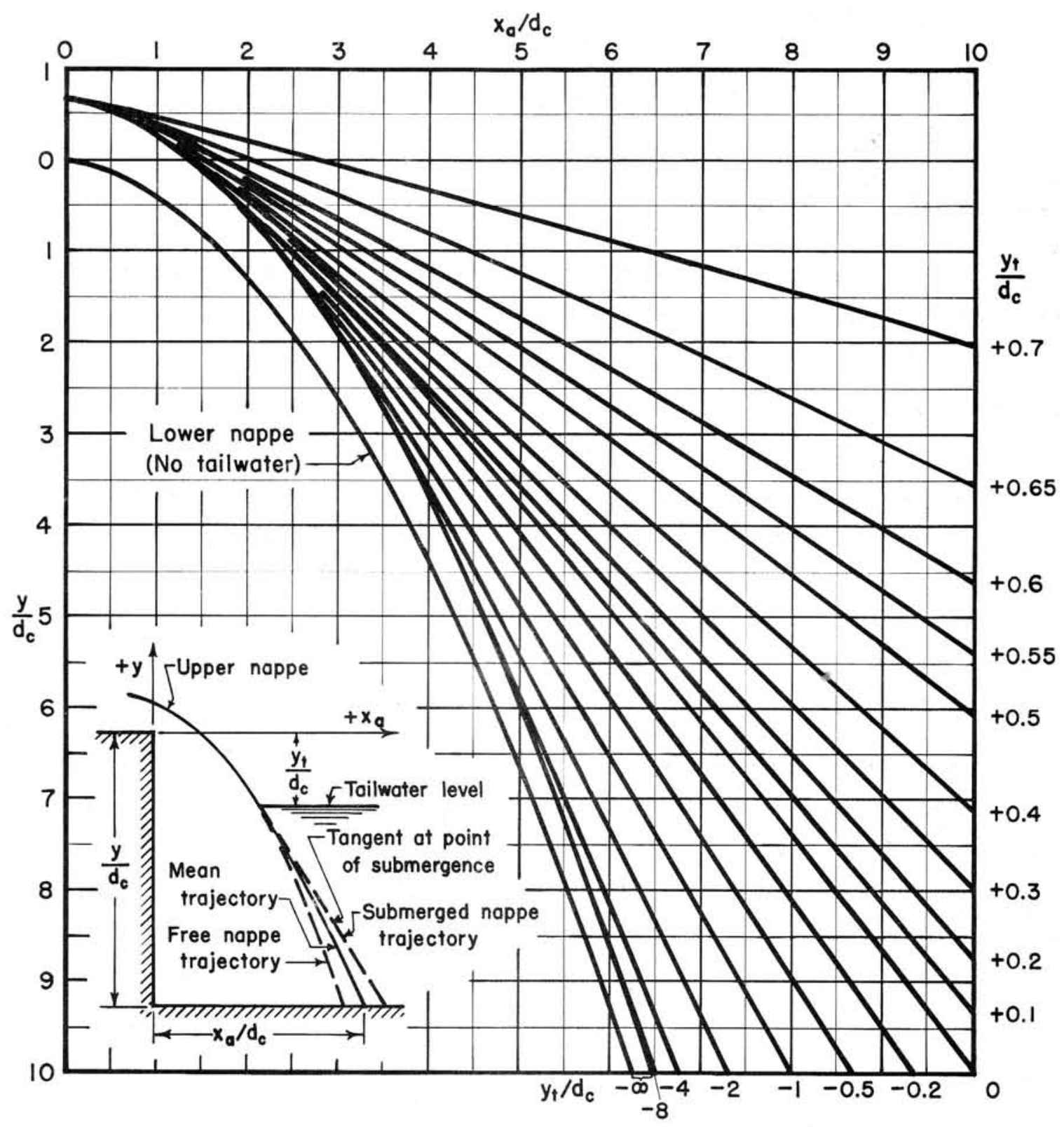

Fig. 2 - Design Chart for Determination of $x_{a}$ 
When $y / d_{c}, y_{n} / d_{c}$, or $y_{t} / d_{c}$ exceeds 0.728 , the value under the radical in Eqs. (1), (2), and (3) becomes negative and the roots of the equation are imaginary. However, since the stilling basin length is not affected by the tailwater levels which exceed two-thirds the critical depth approximately, $\left(y_{t} / d_{c}>0.67\right.$, approximately), this limitation is not important here. Referring to Fig. 2, it is suggested that the curve for $y_{t} / d_{c}=0.7$ be used when $y_{t} / d_{c}$ exceeds +0.7 . This rule was used during the laboratory studies with entirely satisfactory results.

\section{Distance to Floor Blocks}

Sufficient distance is required between the point at which the upper nappe strikes the basin floor and the floor blocks to permit the stream to become approximately parallel to the floor before it reaches the blocks. The determination of the optimum dimension proved to be largely a matter of the judgment of the observer. It was desired to make this dimension as small as possible. However, if the floor blocks are too close to the nappe, a high boil is thrown off of the blocks. When the distance between the upper nappe and the floor blocks $x_{b}$ was less than $0.5 \mathrm{~d}_{\mathrm{c}}$, they proved to be largely ineffective. This is shown by the severe bank erosion in Fig. 3a where the floor blocks are located at the point where the upper nappe strikes the stilling basin floor; that is, where $x_{b}=0$. The scour in Fig. 3a is as severe as that in Fig. 3b where no floor blocks are used. When $x_{b}=0.5 d_{c}$ the boil caused by the floor blocks was higher than was considered desirable. When $x_{b}$ was increased to $0.8 d_{c}$, the appearance of the water surface was satisfactory. As shown in Fig. 4, the bed scour was decreased and the blocks gave sufficient protection to the banks so they stood at their angle of repose. The distance $x_{b}=0.8 d_{c}$ was used for all subsequent tests with results that were completely satisfactory.

The early tests to determine $x_{b}$ were made using $a$ pair of longitudinal sills in the stilling basin. Later it was discovered that longitudinal sills are unnecessary if the floor blocks are properly proportioned and spaced. No further study was made to redetermine $x_{b}$. However, the tests made with $x_{b}=0.8 d_{c}$ showed this distance to give satisfactory stilling basin performance. 


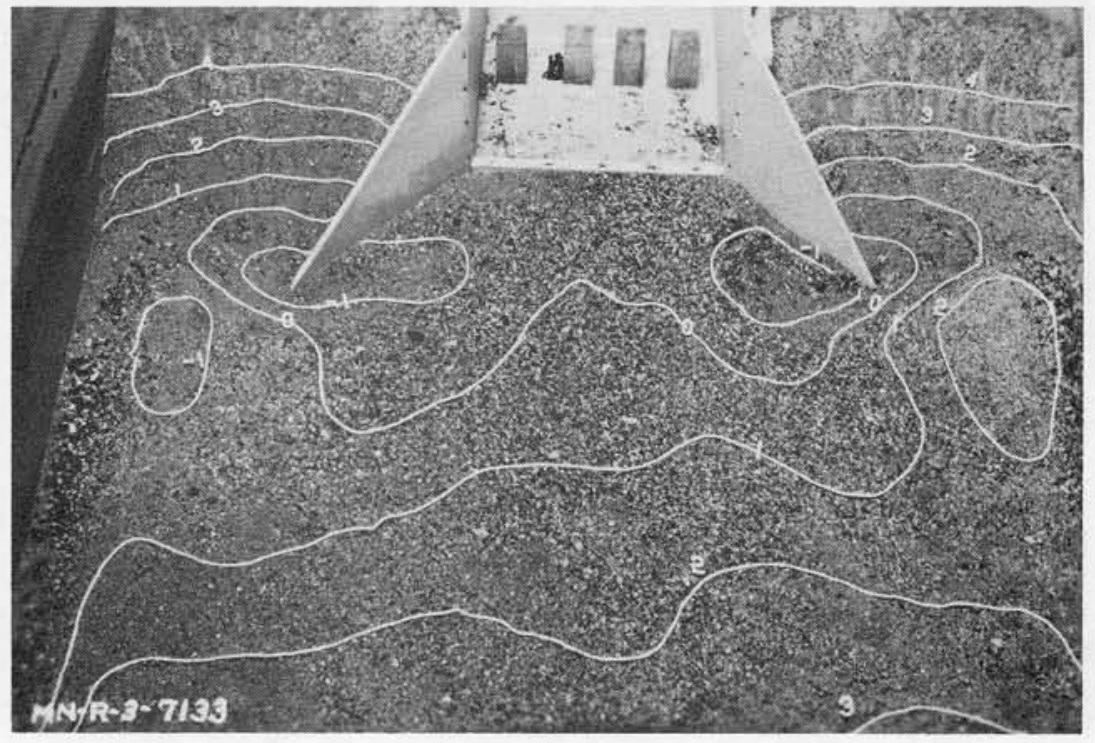

a. Floor Blocks Located at the Point where

the Upper Nappe Strikes the Bas in Floor

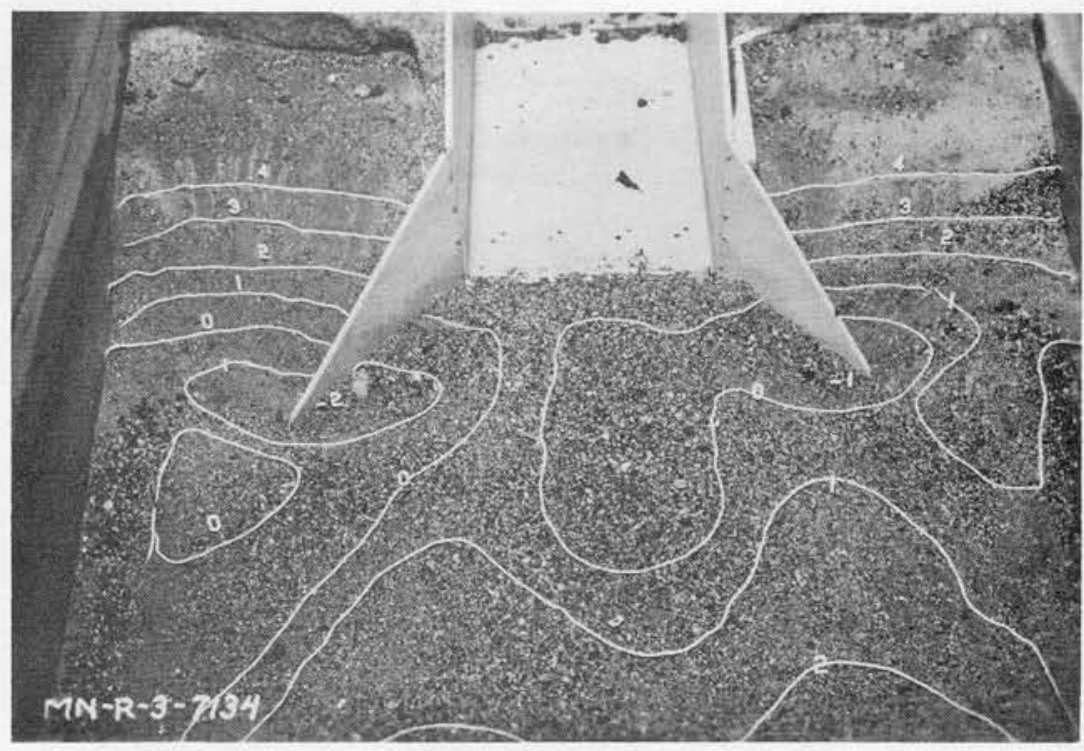

b. No Floor Blocks

Fig. 3 - The Bed Scour Is Deeper than Necessary and the Bank Scour Is Excessive Because of Improper Location or Absence of the Floor Blocks 


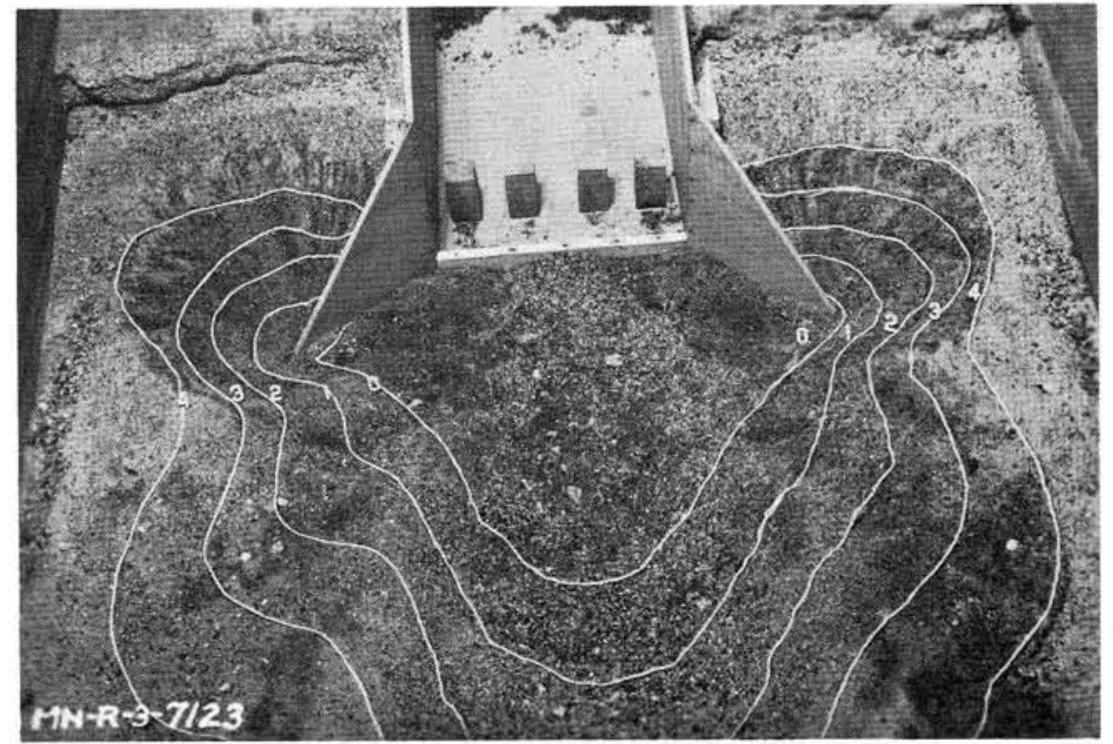

Fig. 4 - Floor Blocks Located $0.8 d_{c}$ from the Point Where the Nappe Strikes the Basin Floor and I.75 d from the End of the Stilling Basin Give Maximum Protection to the Bed and Banks

The recommended distance from the point at which the average of the upper surfaces of the free-falling and submerged nappes strikes the stilling basin floor to the upstream face of the floor blocks is

$$
x_{b}=0.8 d_{c}
$$

Distance to End Sill

If the distance between the floor blocks and the end sill is too short, neither the blocks nor the end sill are fully effective. This is evidenced both by excessive scour of the channel bed and strong eddies which erode the banks and the dam fill.

The minimum distance between the floor blocks and the end sill $x_{c}$ that prevents this excessive scour was found to be $1.75 \mathrm{~d}_{\mathrm{c}}$. Distances greater than $1.75 \mathrm{~d}_{\mathrm{c}}$ had little beneficial effect on the scour pattern. Values of $x_{c}$ as great as $2.75 d_{c}$ were tested. Figure 5 shows that the floor blocks are located too close to the end sill when $x_{c}=0.75 d_{c}$. When $x_{c}=1.75 d_{c}$, as in Fig. 4, the floor blocks are fully effective. 


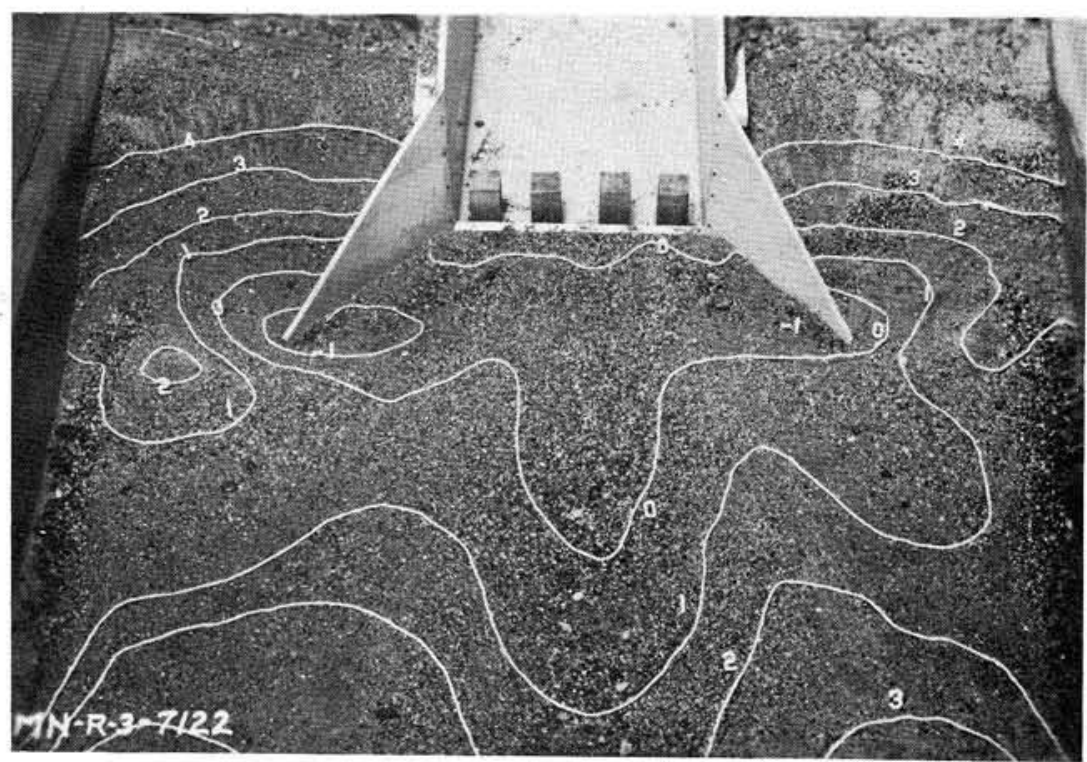

Fig. 5 - Floor Blocks Located $0.75 d_{c}$ from the End of the Stilling Basin Are Ineffective; the Bed Scour is Deeper than Necessary, and the Bank Scour Is Excessive

Here again the judgment of an experienced observer is essential to the determination of the minimum value of $x_{c}$ that gives the most satisfactory performance.

It is recommended, as a result of these tests, that the minimum distance between the upstream face of the floor blocks and the exit of the stilling basin $x_{c}$ be

$$
x_{c} \geq 1.75 d_{c}
$$

Values of $x_{c}$ greater than $1.75 \mathrm{~d}_{c}$ may be used if, for some reason, the basin must be lengthened. The lengths $x_{a}$ and $x_{b}$ should not be varied appreciably from the values given in Eqs. (7) and (8).

\section{Tailwater Depth}

A sufficient depth of tailwater is required so that the water leaving the stilling basin has no opportunity to plunge and scour a hole in the stream bed; the water surface (tailwater level) in the downstream 
channel should be at approximately the same level as the water surface in the stilling basin. This requires the determination of a minimum required tailwater depth for the stilling basin.

The minimum permissible depth of the tailwater above the stilling basin floor $d_{2}$ was found to be $2.15 \mathrm{~d}_{c}$. The tailwater depth over the end sill is $1.75 \mathrm{~d}_{c}$, since the end sill is $0.4 \mathrm{~d}_{c}$ high. The resulting velocity at the exit of the stilling basin is

$$
v=\frac{\sqrt{g_{c}}}{1.75}=3.24 d_{c}^{I / 2}
$$

or, for various values of $H$ and the corresponding values of $d_{c}$,

$\begin{array}{lccccccc}\mathrm{H}= & I & 2 & 3 & 4 & 5 & 6 \mathrm{ft} \\ \mathrm{d}_{\mathrm{c}}= & 0.67 & 1.33 & 2.00 & 2.67 & 3.33 & 4.00 \mathrm{ft} \\ \mathrm{v}= & 2.65 & 3.74 & 4.58 & 5.29 & 5.91 & 6.48 \mathrm{fps}\end{array}$

It is apparent that the adopted minimum tailwater depth results in velocities at the stilling basin exit that are, in most cases, greater than can be tolerated by the ordinary materials comprising natural downstream channels. Therefore, it is assumed that any attempt to further decrease $d_{2}$ would be of no practical value since any decrease in $d_{2}$ would cause higher exit velocities. Even with the present velocities, some widening of the downstream channel near the stilling basin can be expected. This is tolerated because it does not endanger the outlet or the dam fill, and further increases in the minimum tailwater requirement will unnecessarily increase the cost of the outlet.

The results of the tests to determine the minimum acceptable tailwater level are presented in Fig. 6. The tests were conducted as noted in the section describing "Apparatus and Procedure" using tailwater levels varying from an excessively high to an excessively low level. At the conclusion of the tests to determine the tailwater depth, the photographs of the bed contours were studied and given a rating of good, fair, or poor as each individual case warranted. Typical photographs are show in Fig. 7. In Fig. 7a the tailwater level was excessively high $\left(\mathrm{d}_{2}=2.40 \mathrm{~d}_{\mathrm{c}}\right)$. 


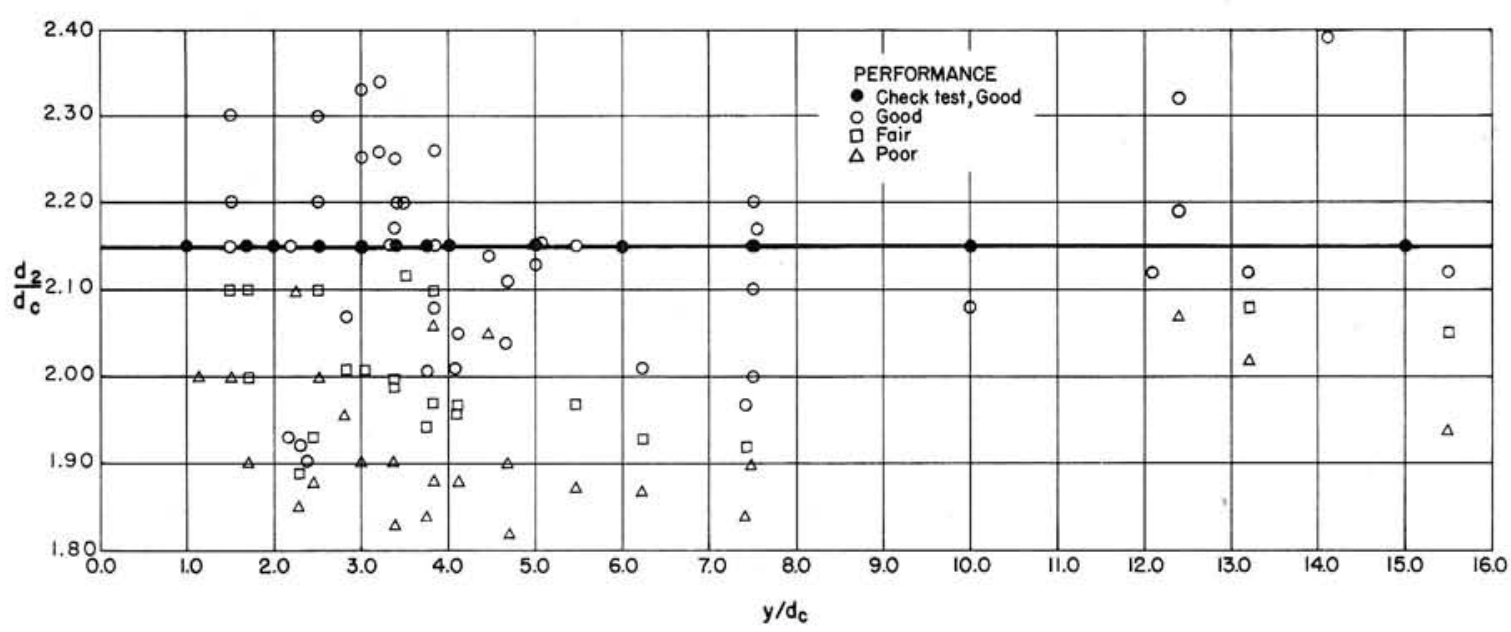

Fig. 6 - Determination of Tailwater Depth

Both the banks and the bed look good; consequently this scour pattern was given a rating of "good." In Fig. $7 \mathrm{~b}$ the tailwater depthwas that adopted for design purposes $\left(d_{2}=2.15 d_{c}\right)$. Here also the scour pattern was given a rating of "good." In Fig. 7c the tailwater depth was a little low $\left(d_{2}=2.00 d_{c}\right)$. The banks are eroded more than is felt desirable and the bed scour is greater than is shown in Figs. $7 \mathrm{a}$ and $7 \mathrm{~b}$. This scour pattern was given a rating of "fair," since it is not very bad, but it does leave something to be desired. The tailwater level for Fig. 7d was excessively low $\left(d_{2}=1.90 d_{c}\right)$, the scour of the banks can be seen to be excessive, and the bed is deepened considerably. This scour pattern was given a rating of "poor."

The results of the analysis of the photographs, when plotted in Fig. 6 against the relative height of the drop, show that the minimum desirable depth of the tailwater $d_{2}$ is $2.15 d_{c}$ and that $d_{2} / d_{c}$ is independent of the relative height of drop. Although there is the possibility that some scour patterns would be "good" when $d_{2}$ is less than $2.15 \mathrm{~d}_{\mathrm{c}}$, tailwater depths lower than $2.15 \mathrm{~d}_{\mathrm{c}}$ would ordinarily give only "fair" or "poor" scour patterns and it is unwise to decrease the design tailwater depth below the recommended value

$$
d_{2}=2.15 d_{c}
$$

Additional verification of the fact that $d_{2} / d_{c}$ should be a constant is presented by Nazir Ahmad [7]. Mr. Ahmad found that $\mathrm{R} / \mathrm{q}^{2 / 3}$ 


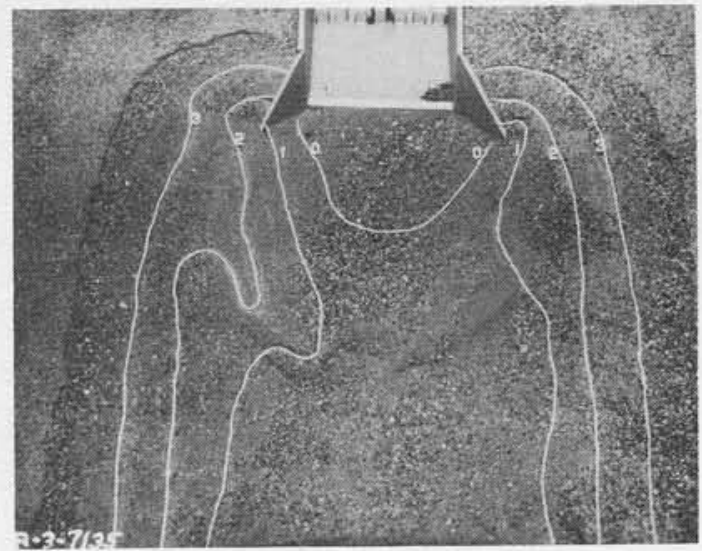

a. "Good" Scour Pattern

High tailwater $\left(\mathrm{d}_{2}=2.40 \mathrm{~d}_{\mathrm{c}}\right)$. Banks and bed are good.

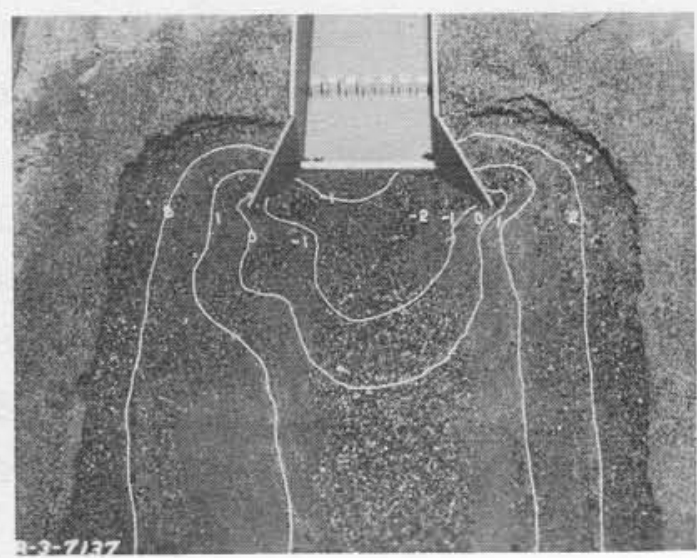

c. "Fair" Scour Pattern

Tailwater slightly low $\left(d_{2}=2.00 d_{c}\right)$. Banks scoured a little and a slight increase in bed scour.

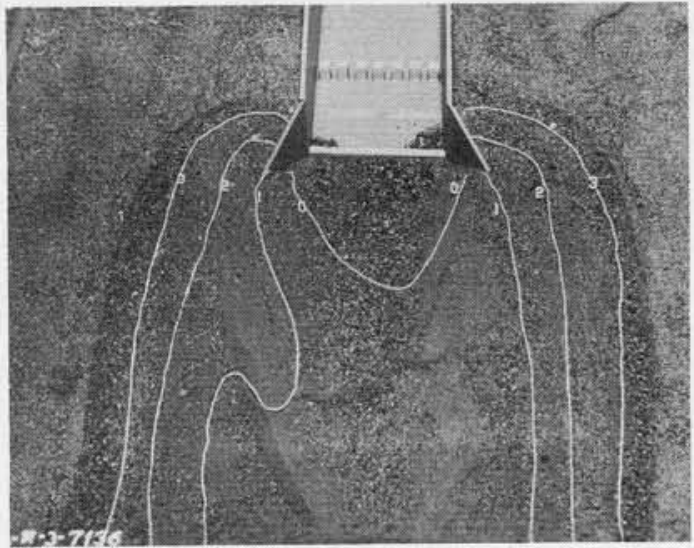

b. "Good" Scour Pattern

Design tailwater $\left(\mathrm{d}_{2}=2.15 \mathrm{~d}_{\mathrm{c}}\right)$. Banks and bed show little scour.

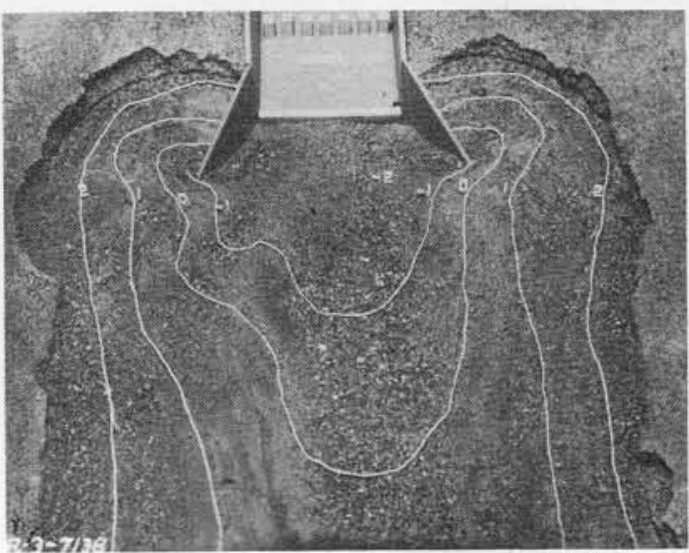

d. "Poor" Scour Pattern

Tailwater excessively low $\left(d_{2}=1.90 \quad d_{c}\right)$. Scour of both banks and bed is excessive.

Fig. 7 - Effect of Tailwater Level on Downstream Scour

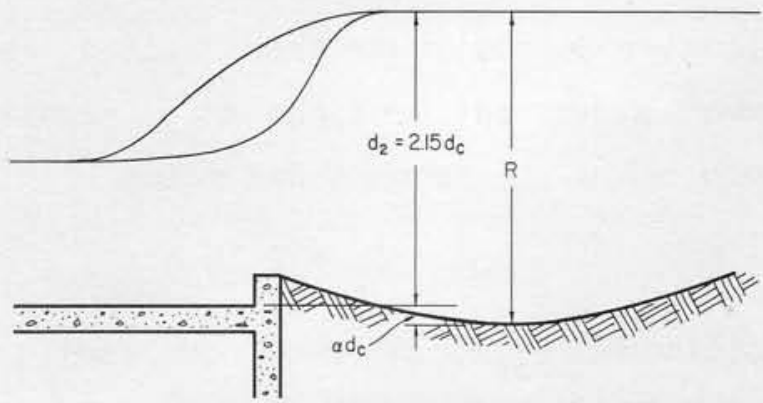

Fig. 8 - Scour near End of Stilling Basin 
is a constent, where $R$ is the depth from the water surface to the bottom of the scour hole (see Fig. 8) and $q$ is the discharge per unit width of the stilling basin. Since

$$
q=v_{c} d_{c}=\sqrt{g d_{c}} d_{c}=g^{1 / 2} d_{c}^{3 / 2}
$$

and

$$
R=d_{2}+a d_{c}=(2.15+a) d_{c}
$$

where $\alpha$ is assumed to be a constant (see Fig. 8),

$$
\frac{\mathrm{R}}{\mathrm{q}^{2 / 3}}=\frac{\mathrm{d}_{2}+a \mathrm{~d}_{\mathrm{c}}}{\left(\mathrm{g}^{1 / 2} \mathrm{~d}_{\mathrm{c}}^{3 / 2}\right)^{2 / 3}}=\frac{\mathrm{d}_{2}+a \mathrm{~d}_{\mathrm{c}}}{\mathrm{g}^{1 / 3} \mathrm{~d}_{\mathrm{c}}}=\frac{\mathrm{d}_{2}}{\mathrm{~g}^{1 / 3} \mathrm{~d}_{\mathrm{c}}}+\frac{a}{\mathrm{~g}^{1 / 3}}=\frac{2.15+\alpha}{\mathrm{g}^{1 / 3}}=\text { constant }
$$

This algebraic manipulation indicates that $\mathrm{R} / \mathrm{q}^{2 / 3}$ and $\mathrm{d}_{2} / \mathrm{d}_{\mathrm{c}}$ are variables which differ in absolute magnitude only by the application of certain constants and further verifies the finding that $\mathrm{d}_{2} / \mathrm{d}_{\mathrm{c}}$ is a constant.

The check tests plotted in Fig. 6 showed that $\mathrm{a}$ tailwater depth of $2.15 d_{c}$ gave entirely satisfactory scour patterns.

\section{Floor Block and End Sill Height}

The heights of the floor blocks and the end sill greatly influence the performance of the stilling basin and help to determine the amount of scour in the downstream channel. It was found that the floor blocks primarily influenced the amount of bank erosion while the primary effect of end sill height was on the depth of bed scour.

The tests made to determine the floor block and end sill heights are surmarized in Table I. After carefully considering these data, the optimurn floor block height was taken as $0.8 \mathrm{~d}_{c}$ and the end sill height $0.4 d_{c}$.

Three things were looked for in comparing the data of Table I: (1) The maximum depth of scour should not be excessive and should be well 
Table I - FLOOR BLOCK AND END SILL HEIGHT

\begin{tabular}{|c|c|c|c|c|c|c|c|c|c|}
\hline \multirow[b]{2}{*}{$\begin{array}{l}\text { Test } \\
\text { No. }\end{array}$} & \multirow[b]{2}{*}{$\begin{array}{l}\text { Long. Sill } \\
\text { Height }\end{array}$} & \multirow[b]{2}{*}{$\begin{array}{l}\text { Floor Block } \\
\text { Height* } \\
\end{array}$} & \multirow[b]{2}{*}{$\begin{array}{l}\text { End Sill } \\
\text { He1 ght* } \\
\end{array}$} & \multicolumn{5}{|c|}{$\begin{array}{c}\text { Depth of Scour } \\
\text { (inches) }\end{array}$} & \multirow[b]{2}{*}{$\begin{array}{c}\text { Bank } \\
\text { Erosion } \\
\end{array}$} \\
\hline & & & & $\begin{array}{c}\mathrm{d}_{c} \\
\text { (inches) }\end{array}$ & Deptr & $\begin{array}{l}\text { mum } \\
\text { Distance } \\
\text { from End } \\
\text { of Basin }\end{array}$ & $\begin{array}{l}\text { Next to } \\
\text { Wingwall }\end{array}$ & $\begin{array}{r}\text { Next to } \\
\text { End S1II } \\
\end{array}$ & \\
\hline $\begin{array}{l}84 \\
85 \\
86 \\
87 \\
88\end{array}$ & $\begin{array}{c}\overline{-} \\
0 . \overline{562} \\
0.562\end{array}$ & $\begin{array}{l}0.750 \\
0.375 \\
0.562 \\
0.562 \\
0.750\end{array}$ & $\begin{array}{l}0.750 \\
0.375 \\
0.375 \\
0.375 \\
0.375\end{array}$ & $\begin{array}{l}2.66 \\
2.66 \\
2.66 \\
2.66 \\
2.66\end{array}$ & $\begin{array}{l}-2+ \\
-1+ \\
-1+ \\
-0.6 \\
-0.6\end{array}$ & $\begin{array}{l}4 \\
5 \\
2 \\
3 \\
3\end{array}$ & $\begin{array}{l}-2+ \\
-1+ \\
-0.5 \\
-0.5 \\
-0.5\end{array}$ & $\begin{array}{l}-2 \\
-7+ \\
-0.8 \\
-0.5 \\
-0.6\end{array}$ & $\begin{array}{l}\text { Poor } \\
\text { Poor } \\
\text { Good } \\
\text { Good } \\
\text { Good }\end{array}$ \\
\hline $\begin{array}{l}89 \\
90 \\
91 \\
92 \\
93\end{array}$ & $\begin{array}{l}0.75 \\
0.375 \\
0.562 \\
0.562 \\
0.600\end{array}$ & $\begin{array}{l}0.750 \\
0.375 \\
0.562 \\
0.562 \\
0.600\end{array}$ & $\begin{array}{l}0.375 \\
0.375 \\
0.375 \\
0.375 \\
0.400\end{array}$ & $\begin{array}{l}2.66 \\
2.66 \\
2.66 \\
2.66 \\
4.00\end{array}$ & $\begin{array}{l}-1.0 \\
-1.0 \\
-1.0 \\
-0.3 \\
-1.8\end{array}$ & $\begin{array}{l}5 \\
4 \\
0 \\
3 \\
5\end{array}$ & $\begin{array}{l}-0.5 \\
-0.5 \\
-0.5 \\
-0.5 \\
-1.3\end{array}$ & $\begin{array}{l}-0.6 \\
-0.5 \\
-1.0 \\
-0.3 \\
-1.3\end{array}$ & $\begin{array}{l}\text { Good } \\
\text { Poor } \\
\text { Good } \\
\text { Poor } \\
\text { Good }\end{array}$ \\
\hline $\begin{array}{l}94 \\
95 \\
96 \\
97 \\
98\end{array}$ & $\begin{array}{l}0.600 \\
0.500 \\
0.500 \\
0.450 \\
0.625\end{array}$ & $\begin{array}{l}0.600 \\
0.500 \\
0.500 \\
0.450 \\
0.625\end{array}$ & $\begin{array}{l}0.300 \\
0.300 \\
0.300 \\
0.300 \\
0.313\end{array}$ & $\begin{array}{l}4.00 \\
4.00 \\
4.00 \\
4.00 \\
4.00\end{array}$ & $\begin{array}{l}-1.3 \\
-1.4 \\
-1.4 \\
-1.4 \\
-1.4\end{array}$ & $\begin{array}{l}3 \\
3 \\
3 \\
2 \\
0\end{array}$ & $\begin{array}{l}-1.0 \\
-1.2 \\
-1.2 \\
-1.2 \\
-1.0\end{array}$ & $\begin{array}{l}-1.2 \\
-1.4 \\
-1.4 \\
-1.4 \\
-1.4\end{array}$ & $\begin{array}{l}\text { Good } \\
\text { Good } \\
\text { Good } \\
\text { Good } \\
\text { Good }\end{array}$ \\
\hline $\begin{array}{l}99 \\
100 \\
101^{* n * 4} \\
102^{* * *} \\
103^{* * *}\end{array}$ & $\begin{array}{r}0.625 \\
0.800 \\
--- \\
0 . \overline{525}\end{array}$ & $\begin{array}{l}0.625 \\
0.800 \\
0.625 \\
0.625 \\
0.625\end{array}$ & $\begin{array}{l}0.625 \\
0.400 \\
0.312 \\
0.375 \\
0.375\end{array}$ & $\begin{array}{l}4.00 \\
4.00 \\
4.00 \\
4.00 \\
4.00\end{array}$ & $\begin{array}{l}-1.3 \\
-1.0 \\
-0.7 \\
-1.0 \\
-1.0\end{array}$ & $\begin{array}{l}5 \\
5 \\
0 \\
6 \\
4\end{array}$ & $\begin{array}{l}-1.1 \\
-0.5 \\
-0.7 \\
-0.8 \\
-0.8\end{array}$ & $\begin{array}{l}-0.8 \\
-0.5 \\
-0.7 \\
-0.6 \\
-0.8\end{array}$ & $\begin{array}{l}\text { Good } \\
\text { Good } \\
\text { Good } \\
\text { Good } \\
\text { Good }\end{array}$ \\
\hline $\begin{array}{l}104^{* H} \\
105 \\
106 \\
107 \\
108\end{array}$ & $\begin{array}{l}0.625 \\
0.625 \\
0.437 \\
0.437 \\
0.437\end{array}$ & $\begin{array}{l}0.625 \\
0.625 \\
0.437 \\
0.437 \\
0.437\end{array}$ & $\begin{array}{l}0.312 \\
0.375 \\
0.312 \\
0.437 \\
0.437\end{array}$ & $\begin{array}{l}4.00 \\
4.00 \\
4.00 \\
4.00 \\
4.00\end{array}$ & $\begin{array}{l}-1.0 \\
-1.0 \\
-1.0 \\
-1.2 \\
-1.2\end{array}$ & $\begin{array}{l}2 \\
3 \\
4 \\
5 \\
5\end{array}$ & $\begin{array}{l}-0.7 \\
-0.8 \\
-0.7 \\
-1.0 \\
-1.0\end{array}$ & $\begin{array}{l}-0.8 \\
-0.8 \\
-0.8 \\
-0.8 \\
-0.8\end{array}$ & $\begin{array}{l}\text { Good } \\
\text { Good } \\
\text { Fair } \\
\text { Poor } \\
\text { Poor }\end{array}$ \\
\hline $\begin{array}{l}109 \\
110 \\
111 \\
116 \\
117\end{array}$ & $\begin{array}{l}0.625 \\
0.625 \\
0.375 \\
1.250 \\
0.625\end{array}$ & $\begin{array}{l}0.625 \\
0.437 \\
0.375 \\
1.250 \\
1.250\end{array}$ & $\begin{array}{l}0.250 \\
0.250 \\
0.250 \\
0.625 \\
0.375\end{array}$ & $\begin{array}{l}4.00 \\
4.00 \\
4.00 \\
4.00 \\
4.00\end{array}$ & $\begin{array}{l}-1.2 \\
-0.6 \\
-1.0 \\
-7.0 \\
-1.2\end{array}$ & $\begin{array}{l}0 \\
0 \\
4 \\
4 \\
2\end{array}$ & $\begin{array}{l}-1.1 \\
-0.6 \\
-0.7 \\
-0.5 \\
-1.0\end{array}$ & $\begin{array}{l}-1.2 \\
-0.6 \\
-0.7 \\
-0.5 \\
-7.0\end{array}$ & $\begin{array}{l}\text { Fair } \\
\text { Fair } \\
\text { Fair } \\
\text { Good } \\
\text { Fair }\end{array}$ \\
\hline $\begin{array}{l}118 \\
124 \\
125 \\
126 \\
127 \\
128\end{array}$ & $\begin{array}{l}0.625 \\
0.500 \\
0.600 \\
0.800 \\
0.800 \\
0.600\end{array}$ & $\begin{array}{l}1.250 \\
0.500 \\
0.600 \\
0.800 \\
0.800 \\
0.600\end{array}$ & $\begin{array}{l}0.375 \\
0.300 \\
0.400 \\
0.500 \\
0.400 \\
\therefore .300\end{array}$ & $\begin{array}{l}4.00 \\
3.33 \\
3.23 \\
3.33 \\
3.33 \\
3.37\end{array}$ & $\begin{array}{l}-2.0 \\
-3.0 \\
-0.4 \\
-0.1 \\
-1.0 \\
-2.0\end{array}$ & $\begin{array}{l}5 \\
5 \\
-0 \\
0 \\
5 \\
6\end{array}$ & $\begin{array}{l}-2.0 \\
-3.0 \\
-0.4 \\
-0.1 \\
-0.5 \\
-2.0\end{array}$ & $\begin{array}{r}-0.5 \\
0.0 \\
-0.4 \\
-0.4 \\
-0.5 \\
-1.0\end{array}$ & $\begin{array}{l}\text { Poor } \\
\text { Poor } \\
\text { Poor } \\
\text { Pair } \\
\text { Oood } \\
\text { Poor }\end{array}$ \\
\hline
\end{tabular}

away from the downstream end of the outlet; (2) the scour along the wingwalls and at the end of the basin should be a minimum; and (3) the bank erosion should have a "good" rating, a "fair" or "poor" rating indicating that eddies had washed away an excessive amount of bank material. A study of Table I shows that Tests No. 87, 88, 89, 100, 116, and 127 best meet these criteria. The relative floor block and end sill heights for these tests were:

$\begin{array}{lcccccc}\text { Test No. } & 87 & 88 & 89 & 100 & 116 & 127 \\ \text { Relative floor block height } & 0.562 & 0.750 & 0.750 & 0.800 & 1.250 & 0.800 \\ \text { Relative end sill height } & 0.375 & 0.375 & 0.375 & 0.400 & 0.625 & 0.400\end{array}$


With the exception of Test No. 87, all floor blocks were twice as high as the end sill. Both higher and lower ratios of floor block height to end sill height produced either a greater depth of scour next to the end sill and wingwalls, or poorer bank erosion, or both. Also, with the exception of Tests No. 87 and 1l6, all end sills were approximately $0.4 \mathrm{~d}_{c}$ high and all floor blocks were $0.8 \mathrm{~d}_{\mathrm{c}}$ high. The lesser height was selected because the tailwater depth was greater for these tests than was later determined to be the best minimum depth. When the tailwater depth was reduced, there was a greater opportunity for the stream to scour the bed in plunging over the high end sill than in passing over the lower end sill.

Although longitudinal sills were employed during most of the tests summarized in Table I, subsequent tests without longitudinal sills and with floor blocks and end sill heights of $0.8 d_{c}$ and $0.4 d_{c}$, respectively, showed that these heights were completely satisfactory.

As a result of the tests made to determine the block and sill heights, it is recommended that:

$$
\begin{aligned}
& \text { the height of the floor blocks be } 0.8 d_{c} \\
& \text { the height of the end sill be } 0.4 d_{c}
\end{aligned}
$$

\section{Floor Block Width and Spacing}

The actual width and spacing of the floor blocks, as well as the proportion of the stilling basin width occupied by the blocks, have been found to have an important effect on the performance in previous stilling basin studies. The straight drop spillway stilling basin was no exception. If the floor blocks are too wide, they do not break up the stream into small enough segments to dissipate the high-velocity flow in a short distance. If the blocks occupy too much of the stilling basin width, their composite action becomes more like a solid sill than like individual blocks. Finally, if the blocks occupy an insufficient proportion of the basin width they become ineffective. There is, therefore, an optimum spacing and proportion of the basin width occupied by the blocks that must be determined. The primary effect of varying the floor block width and spacing is on the amount of bank erosion obtained.

The tests made to determine the block width and spacing are summarized in Table II. The same things were looked for in Table II when 
comparing the effect of the floor block width and spacing as were looked for in Table I when comparing the effect of the floor block and end sill height. A study of Table II shows that the block width has no detectable effect on the bed or bank scour. However, it will be shown in the section on "sidewall height" that wide blocks cause a high boil in the basin and thus require higher sidewalls. This indicates that there is a limit to the width of the individual blocks that must be taken into account when designing stilling basins.

Table II - FLOOR BLOCK WIDTH AND SPACING

\begin{tabular}{|c|c|c|c|c|c|c|c|c|c|c|}
\hline \multirow[b]{2}{*}{$\begin{array}{l}\text { Test } \\
\text { No. }\end{array}$} & \multirow[b]{2}{*}{$\begin{array}{c}d_{c} \\
\text { (inches) }\end{array}$} & \multirow[b]{2}{*}{${\underline{d_{2}}}^{*}$} & \multirow[b]{2}{*}{$y^{* *}$} & \multirow[b]{2}{*}{$\begin{array}{l}\text { Block } \\
\text { Width" }\end{array}$} & \multirow{2}{*}{$\begin{array}{c}\text { Basin width } \\
\text { Occupied } \\
\text { by Blocks } \\
\text { (per cent) } \\
\end{array}$} & \multirow{2}{*}{$\begin{array}{l}\text { Long } \\
\text { Silis }\end{array}$} & \multicolumn{3}{|c|}{$\begin{array}{l}\text { Depth of Scour } \\
\text { (inches) }\end{array}$} & \multirow[b]{2}{*}{$\begin{array}{l}\text { Bank } \\
\text { Erosion }\end{array}$} \\
\hline & & & & & & & $\begin{array}{l}\text { Maximum } \\
\text { Depth }\end{array}$ & $\begin{array}{l}\text { Next to } \\
\text { Wingwall }\end{array}$ & $\begin{array}{l}\text { At Fnd of } \\
\text { Basin }\end{array}$ & \\
\hline $\begin{array}{l}188 \\
189 \\
190 \\
191\end{array}$ & $\begin{array}{l}4.00 \\
4.00 \\
4.00 \\
4.00\end{array}$ & $\begin{array}{l}2.30 \\
2.30 \\
2.30 \\
2.30\end{array}$ & $\begin{array}{l}2.50 \\
2.50 \\
2.50 \\
2.50\end{array}$ & $\begin{array}{l}0.25 \\
0.25 \\
0.25 \\
0.25\end{array}$ & $\begin{array}{l}50.0 \\
41.7 \\
41.7 \\
50.0\end{array}$ & $\begin{array}{l}2 \\
2 \\
2 \\
0\end{array}$ & $\begin{array}{l}-1.5 \\
-1.5 \\
-1.5 \\
-1.5\end{array}$ & $\begin{array}{l}-1.2 \\
-1.2 \\
-1.2 \\
-1.2\end{array}$ & $\begin{array}{l}-0.8 \\
-0.8 \\
-0.8 \\
-0.8\end{array}$ & $\begin{array}{l}\text { Good } \\
\text { Poor } \\
\text { Poor } \\
\text { Fair }\end{array}$ \\
\hline $\begin{array}{l}192 \\
193 \\
194 \\
195\end{array}$ & $\begin{array}{l}4.00 \\
4.00 \\
4.00 \\
4.00\end{array}$ & $\begin{array}{l}2.30 \\
2.30 \\
2.30 \\
2.30\end{array}$ & $\begin{array}{l}2.50 \\
2.50 \\
2.50 \\
2.50\end{array}$ & $\begin{array}{l}0.25 \\
0.25 \\
0.375 \\
0.75\end{array}$ & $\begin{array}{l}50.0 \\
50.0 \\
50.0 \\
50.0\end{array}$ & $\begin{array}{l}2 \\
4 \\
0 \\
0\end{array}$ & $\begin{array}{l}-2.0 \\
-7.5 \\
-0.5 \\
-1.5\end{array}$ & $\begin{array}{l}-1.5 \\
-1.3 \\
-0.3 \\
-1.3\end{array}$ & $\begin{array}{l}-0.8 \\
-0.3 \\
-0.3 \\
-1.3\end{array}$ & $\begin{array}{l}\text { Fair } \\
\text { Fair } \\
\text { Good } \\
\text { Good }\end{array}$ \\
\hline $\begin{array}{l}196 \\
198 \\
199 \\
201\end{array}$ & $\begin{array}{l}4.00 \\
4.00 \\
4.00 \\
3.33\end{array}$ & $\begin{array}{l}2.30 \\
2.30 \\
2.30 \\
2.15\end{array}$ & $\begin{array}{l}2.50 \\
2.50 \\
2.50 \\
2.20\end{array}$ & $\begin{array}{l}0.50 \\
0.45 \\
0.30 \\
0.145\end{array}$ & $\begin{array}{l}50.0 \\
60.0 \\
40.0 \\
50.0\end{array}$ & $\begin{array}{l}0 \\
0 \\
0 \\
0\end{array}$ & $\begin{array}{l}-1.5 \\
-1.3 \\
-2.0 \\
-1.5\end{array}$ & $\begin{array}{l}-1.3 \\
-1.3 \\
-1.8 \\
-1.5\end{array}$ & $\begin{array}{l}-0.8 \\
-0.8 \\
-0.8 \\
-0.8\end{array}$ & $\begin{array}{l}\text { Good } \\
\text { Good } \\
\text { Poor } \\
\text { Good }\end{array}$ \\
\hline $\begin{array}{l}202 \\
203 \\
204^{* * *} \\
205 \\
206\end{array}$ & $\begin{array}{l}3.33 \\
3.33 \\
2.67 \\
2.67 \\
4.00\end{array}$ & $\begin{array}{l}2.15 \\
2.15 \\
2.00 \\
2.00 \\
2.30\end{array}$ & $\begin{array}{l}2.20 \\
2.20 \\
2.25 \\
2.25 \\
1.75\end{array}$ & $\begin{array}{l}0.54 \\
0.50 \\
0.40 \\
0.40 \\
0.40\end{array}$ & $\begin{array}{l}60.0 \\
55.0 \\
50.0 \\
50.0 \\
53.3\end{array}$ & $\begin{array}{l}0 \\
0 \\
0 \\
0 \\
0\end{array}$ & $\begin{array}{l}-1.7 \\
-1.5 \\
-2.4 \\
-1.3 \\
-0.8\end{array}$ & $\begin{array}{l}-0.8 \\
-1.2 \\
-2.0 \\
-0.8 \\
-0.5\end{array}$ & $\begin{array}{l}-1.2 \\
-1.2 \\
-1.2 \\
-0.8 \\
-0.3\end{array}$ & $\begin{array}{l}\text { Good } \\
\text { Good } \\
\text { Good } \\
\text { Good } \\
\text { Good }\end{array}$ \\
\hline
\end{tabular}

Although the width of individual blocks is not critical, it is essential that a sufficient number of floor blocks be used to break up the nappe into small streams. These small streams then decay into isotropic turbulence. The distance required for this decay to take place depends to a large extent on the size of the streams into which the nappe is broken by the floor blocks. Because of these considerations, it is recommended that the floor blocks be $0.4 \mathrm{~d}_{c}$ wide. A variation of $0.15 \mathrm{~d}_{c}$ from this limit is permissible in order to fit the blocks into the stilling basin and avoid odd dimensions. However, it is stressed that the recommended floor block width is $0.4 \mathrm{~d}_{\mathrm{c}}$ and that this dimension should be held as closely as is practically possible. 
The floor blocks for the tests were ordinarily square in plan. However, for Test No. 204 (see Table II), the floor blocks were $0.4 \mathrm{~d}_{c}$ wide by $0.75 \mathrm{~d}_{\mathrm{c}}$ long, and the scour depths are somewhat greater than those for companion Test No. 205 where the floor blocks were $0.4 d_{c}$ wide by $0.4 d_{c}$ long. The minimum permissible distance between the floor blocks and the basin exit is quite short and this entire distance is required for energy dissipation. If some of this space is occupied by extra long floor blocks, it will not be available for energy dissipation, and additional scour in the downstream channel will result. It is therefore recommended that the floor blocks be square in plan with the dimensions indicated in the preceding paragraph.

Study of Table II also shows that the proportion of the basin width occupied by the floor blocks should be between 50 and 60 per cent of the stilling basin width. This is also shown in Fig. 9, where the contours of the scour are almost the same in Fig. $9 \mathrm{~b}$ as they are in Fig. 9c. For these photographs the portion of the basin width occupied by the blocks is 50 and 60 per cent, respectively. In Fig. 9a, where the proportion is 40 per cent, the maximum depth of scour is greater and the bank erosion is much more severe.

The tests show that longitudinal sills are neither significantly beneficial nor harmful as regards the hydraulic performance of the stilling basin. The longitudinal sills may be used to strengthen the stilling basin floor if this proves desirable. If longitudinal sills are used, they should be located to pass through a floor block. Their height should be determined by structural requirements.

Surmarizing: The width, spacing, and length of the floor blocks should be approximately $0.4 d_{c}$ with an extreme variation of $\pm 0.15 d_{c}$; it is not necessary that the floor block width and spacing be exactly equal, but the blocks should occupy between 50 and 60 per cent of the stilling basin width; a half space should be located next to the basin sidewall; and longitudinal sills passing through the floor blocks may be used for structural purposes without detrimental hydraulic effects. 


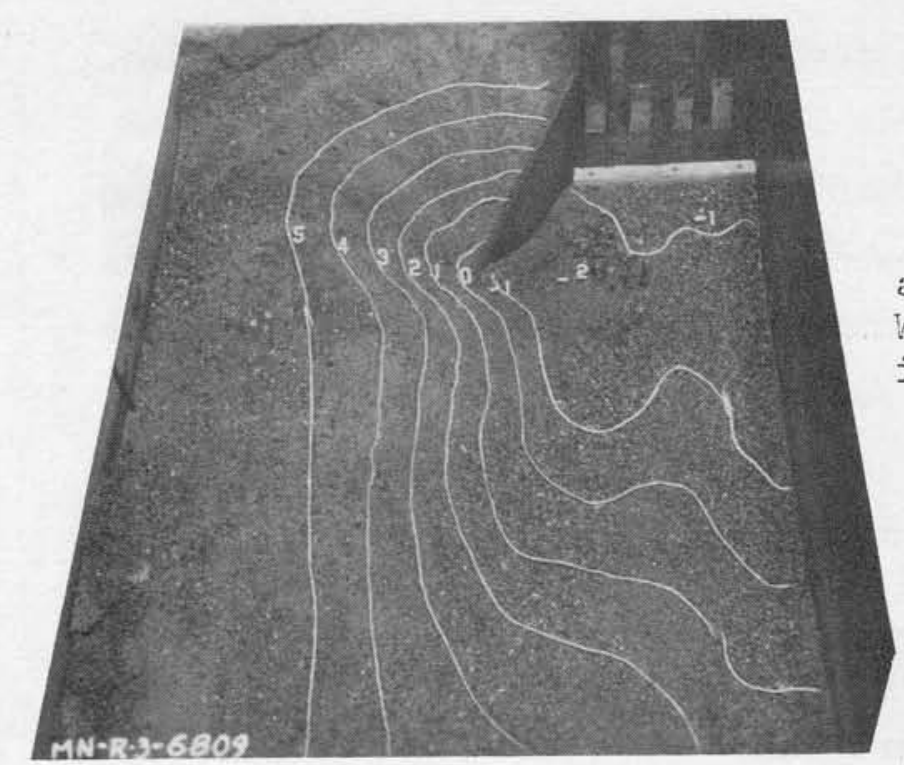

a. Blocks Occupy 40 Per Cent of Basin Width. Test No. 199. Bank erosion is severe and bed scour is excessive.

b. Blocks Occupy 50 Per Cent of Basin Width. Test No. 196. Bank and bed erosion are good.
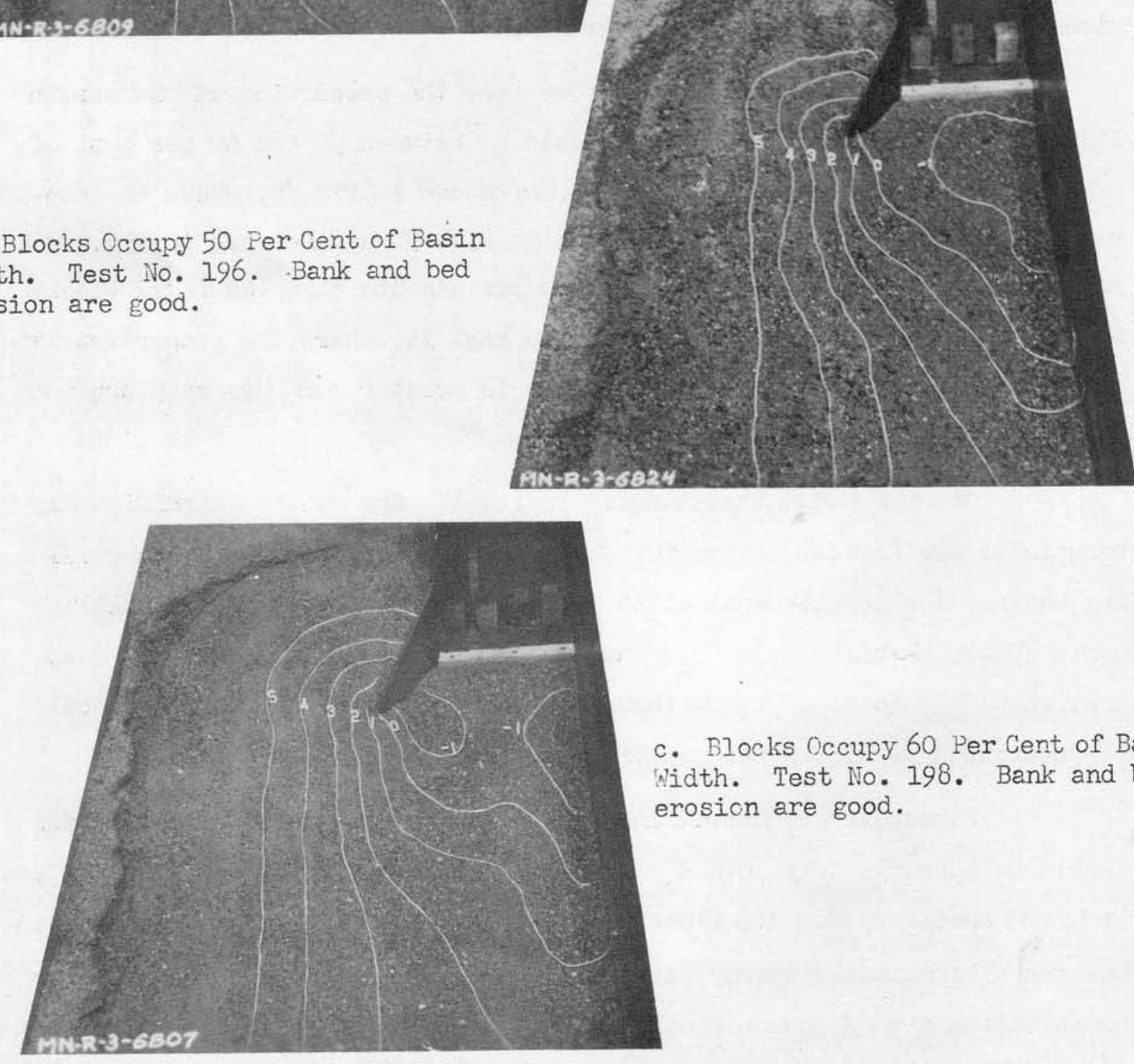

c. Blocks Occupy 60 Per Cent of Basin Width. Test No. 198. Bank and bed erosion are good.

Fig. 9 - Effect of Proportion of Basin Width Occupied by Floor Blocks on Scour of Bed and Banks 


\section{Sidewall Height}

An additional height of sidewall is required above the nominal tailwater level to prevent overtopping of the sidewalls as a result of natural water surface fluctuations, turbulence within the stilling basin caused by the floor blocks, and boils and standing waves resulting from the floor blocks and end sill.

The results of the tests to determine the height of the boils and standing waves are given in Table III. Inspection of the table reveals

\section{Table III - SIDEWALI HEIGHT TESTS}

Basin Dimensions Are Those Recommended in This Paper

$\begin{array}{ccc}\begin{array}{ccc}\text { Check } \\ \text { Test No. }\end{array} & \begin{array}{c}d_{c} \\ (f t)\end{array} & \underline{y^{*}} \\ 23 & 0.400 & 2.50 \\ 24 & 0.300 & 3.33 \\ 29 & 0.250 & 4.00 \\ 30 & 0.200 & 5.00\end{array}$

\begin{tabular}{|c|c|}
\hline \multicolumn{2}{|c|}{ Height of Boil* } \\
\hline $\begin{array}{l}\text { At Floor } \\
\text { Blocks }\end{array}$ & $\begin{array}{l}\text { At End } \\
\text { Sill }\end{array}$ \\
\hline 2.50 & 2.40 \\
\hline 2.66 & 2.40 \\
\hline 2.72 & 2.32 \\
\hline 2.75 & 2.40 \\
\hline
\end{tabular}

*In terms of $d_{c}$ above stilling basin floor

that the height of the boil or standing wave at the end sill is $2.40 d_{c}$ above the stilling basin floor. Since the tailwater depth $d_{2}$ is $2.15 d_{c}$, the height of the boil at the end of the basin is $0.25 d_{c}$ above the tailwater surface. However, the highest boil is caused by the floor blocks. The maximum boil height at this location is shown in Table III to be $2.75 d_{c}$ or $0.60 d_{c}$ above the tailwater level.

It is recommended, as a result of the tests summarized here, that the top of the sidewalls be located in a minimum distance of $0.85 d_{c}$ above the tailwater level. This will give a freeboard above the maximum observed boil height of $0.25 \mathrm{~d}_{c}$. It is believed that this is the minimum freeboard that should be permitted. Even with this freeboard, spray and splash will probably overtop the sidewalls occasionally. 


\section{Wingwalls}

Wingwalls located at an angle of $45^{\circ}$ with the stilling basin centerline and having a top slope of $I$ on $I$ were used throughout the straight drop spillway stilling basin test progran. No special wingwall tests were made because the results of tests on the box inlet drop spillway outlet [8] and on the SAF stilling basin [3] had previously indicated that the wingwall form used here would be satisfactory.

The tests on the straight drop spillway stilling basin showed these wingwalls to be completely satisfactory. The material in back of the wingwall did not erode at all but rested at its natural angle of repose. The scour at the end of the wingwall was not greater than anticipated from previous tests. These conclusions assume, of course, a properly proportioned stilling basin.

It is recomended that the wingwalls be located at an angle of $45^{\circ}$ with the stilling basin centerline and that the top slope be $I$ on $I$. If it is desirable to use other wingwall positions or top slopes, it is suggested that reference be made to publications [4] or [8] for the probable effect of such changes.

\section{Approach Channel}

The shape of the approach channel was found to affect the stilling basin performance. It is important, therefore, that certain minimum conditions be met with regard to the shape of the approach channel. These conditions are not unduly restrictive.

In all instances the bed of the approach channel was level with the crest of the straight drop spillway. This eliminated the contraction of the under surface of the nappe. Deviation from this level approach channel can be expected to affect the position at which the nappe strikes the stilling basin floor and, as a result, the length of the stilling basin.

For some tests the approach channel was very wide, the approach channel floor was horizontal, and no dikes were used; that is, the headwall extension was carried across the full width of the approach chennel. For this approach channel, the contraction at the ends of the spillway 
notch was so great that the ends of the nappe landed well away from the stilling basin sidewalls. Thus, the full width of the stilling basin was not used to dissipate the energy in the nappe, and the higher velocities concentrated at the center of the outlet caused additional scour in the downstream channel.

Correction of this poor flow distribution in the stilling basin and downstream channel is quite simple. It is accomplished by properly shaping the approach channel to reduce the contraction at the ends of the spillway. If the toe of the dike is located at the end of the notch, the dike slope along the headwall extension is 1 on 2 or steeper, the top width of the dike is located downstream from the headwall, and the upstream slope of the dike is 3 on 1 or flatter; the contraction will be suppressed sufficiently to result in acceptable stilling basin performance. However, it is felt that ordinarily the dike top width will, for reasons of economy, be located upstream of the headwall. This should give, in effect, an approach channel with 1 on 2 side slopes and a bottom width equal to the notch width. This further suppresses the contraction at the ends of the spillway opening and results in even better stilling basin performance. This latter approach channel shape approximates the condition of a ditch having a bottom width equal to the notch length. The suppression of the end contractions for the ditch approach channel shape will insure satisfactory stilling basin performance.

One other approach channel caution must be mentioned. The bed and banks just upstream from the spillway crest will be scoured if they are not protected by riprap or paving. Tentatively, it is suggested that this protection be extended upstream a distance equal to twice the depth of the spillway notch. The heaviest stone should be located close to the notch with particularly heavy stone in the vicinity of the ends of the notch.

\section{Aeration Under Nappe}

The air removed from beneath the nappe by the plunging water must be replaced in order to prevent low pressures which might cause fluctuation of the nappe and extra loads on the structure. Fortunately, the recommended approach channel form permits sufficient contraction at the 
ends of the weir notch so that air has access to the underside of the nappe. Therefore, no special provision for aeration is necessary. In fact, the use of offsets or widening of the stilling basin to provide aeration is not recommended since it adversely affects the stilling basin performance.

If buttresses are used to support the headwall, access of air to the space between the buttresses may be cut off. In this case it is necessary to provide aeration passages through the buttresses. G. H. Hickox has shown how the size of these air passages can be determined [9].

\section{Check Tests}

A series of check tests was planned and carried out after the design rules for the stilling basin had been established. The purpose of these tests was to check the overall performance of the stilling basin under the complete range of conditions for which it is useful.

The check tests and the results obtained from them are summarized in Table IV. In every case, the stilling basin performed satisfactorily and according to expectations. In other words, the check tests verified the adequacy of the design mules.

Table IV - SUMMARY OF CHECK TESTS

\begin{tabular}{|c|c|c|c|c|c|c|c|c|c|c|}
\hline \multirow[b]{3}{*}{$\begin{array}{c}\text { Check } \\
\text { Test No. }\end{array}$} & \multirow[b]{3}{*}{$\underline{d_{c}}$} & \multirow[b]{3}{*}{$\mathrm{y}^{3+2 k t}$} & \multicolumn{5}{|c|}{$\begin{array}{l}\text { Scour } \\
\text { (feet) }\end{array}$} & \multirow[b]{3}{*}{$\begin{array}{c}\text { Bank } \\
\text { Erosion }\end{array}$} & \multirow{2}{*}{\multicolumn{2}{|c|}{ Helght of Boil }} \\
\hline & & & \multirow[b]{2}{*}{$\underline{y_{t}^{* * *}}$} & \multicolumn{2}{|c|}{ Maximum } & \multirow{2}{*}{$\begin{array}{l}\text { Next to } \\
\text { Wingwall }\end{array}$} & \multirow[b]{2}{*}{$\begin{array}{l}\text { Next to } \\
\text { End Sill }\end{array}$} & & & \\
\hline & & & & Depth & $\begin{array}{l}\text { from End } \\
\text { of Basin }\end{array}$ & & & & $\begin{array}{l}\text { At Floor } \\
\text { Blocks }\end{array}$ & $\begin{array}{l}\text { At End } \\
\text { Sill }\end{array}$ \\
\hline $\begin{array}{r}6 \\
7 \\
8 \\
9 \\
10 \\
11 \\
12\end{array}$ & $\begin{array}{l}0.1 \\
0.5 \\
0.4 \\
0.3 \\
0.3 \\
0.2 \\
0.1\end{array}$ & $\begin{array}{r}10.00 \\
3.00 \\
3.75 \\
5.00 \\
5.00 \\
7.50 \\
10.00\end{array}$ & $\begin{array}{r}-8.25 \\
-1.25 \\
-2.00 \\
+0.33 \\
-3.25 \\
-5.75 \\
-13.25\end{array}$ & $\begin{array}{l}0.10 \\
0.10 \\
0.10 \\
0.23 \\
0.10 \\
0.14 \\
0.10\end{array}$ & $\begin{array}{l}0.1 \\
1.2 \\
1.0 \\
1.4 \\
1.2 \\
1.3 \\
0.8\end{array}$ & $\begin{array}{l}0.04 \\
0.04 \\
0.04 \\
0.15 \\
0.03 \\
0.02 \\
0.02\end{array}$ & $\begin{array}{l}0.05 \\
0.04 \\
0.01 \\
0.12 \\
0.04 \\
0.08 \\
0.07\end{array}$ & $\begin{array}{l}\text { Very Good } \\
\text { Good } \\
\text { Good } \\
\text { Good } \\
\text { Good } \\
\text { Very Good } \\
\text { Very Good }\end{array}$ & & \\
\hline $\begin{array}{l}13 \\
14 \\
15 \\
16 \\
17\end{array}$ & $\begin{array}{l}0.3 \\
0.25 \\
0.2 \\
0.15 \\
0.1\end{array}$ & $\begin{array}{l}1.67 \\
2.00 \\
2.50 \\
3.33 \\
5.00\end{array}$ & $\begin{array}{l}+0.083 \\
-0.025 \\
-0.75 \\
-1.58 \\
-4.75\end{array}$ & $\begin{array}{l}0.10 \\
0.13 \\
0.12 \\
0.10 \\
0.05\end{array}$ & $\begin{array}{l}1.0 \\
1.3 \\
0.5 \\
0.7 \\
0.5\end{array}$ & $\begin{array}{l}0.04 \\
0.07 \\
0.02 \\
0.02 \\
0.03^{\text {* }}\end{array}$ & $\begin{array}{l}0.04 \\
0.07 \\
0.07 \\
0.07 \\
0.05\end{array}$ & $\begin{array}{l}\text { Good } \\
\text { Very Good } \\
\text { Very Good } \\
\text { Very Good } \\
\text { Very Good }\end{array}$ & & \\
\hline $\begin{array}{l}18 \\
19 \\
20 \\
21 \\
22\end{array}$ & $\begin{array}{l}0.4 \\
0.4 \\
0.4 \\
0.4 \\
0.4\end{array}$ & $\begin{array}{l}2.50 \\
2.50 \\
2.50 \\
2.50 \\
2.50\end{array}$ & $\begin{array}{r}+0.50 \\
+0.60 \\
+0.70 \\
0.00 \\
-0.75\end{array}$ & $\begin{array}{l}0.14 \\
0.05 \\
0.05 \\
0.15 \\
0.08\end{array}$ & $\begin{array}{l}1.2 \\
0.8 \\
0.8 \\
1.4 \\
1.3\end{array}$ & $\begin{array}{l}0.10 \\
0.05^{*} \\
0.05^{5 * x *} \\
0.12 \\
0.05\end{array}$ & $\begin{array}{l}0.12 \\
0.02 \\
0.02 \\
0.08 \\
0.08\end{array}$ & $\begin{array}{l}\text { Good } \\
\text { Good } \\
\text { Good } \\
\text { Good } \\
\text { Good }\end{array}$ & & \\
\hline $\begin{array}{l}23 \\
24 \\
29 \\
30\end{array}$ & $\begin{array}{l}0.4 \\
0.3 \\
0.25 \\
0.20\end{array}$ & $\begin{array}{l}2.50 \\
3.33 \\
4.00 \\
5.00\end{array}$ & $\begin{array}{l}-0.35 \\
-1.18 \\
-1.84 \\
-2.84\end{array}$ & $\begin{array}{l}0.09 \\
0.07 \\
0.16\end{array}$ & $\begin{array}{l}1.2 \\
0.6 \\
0.6\end{array}$ & $\begin{array}{l}0.06 \\
0.06 \\
0.00\end{array}$ & $\begin{array}{l}0.06 \\
0.05 \\
0.07\end{array}$ & $\begin{array}{l}\text { Good } \\
\text { Good } \\
\text { Good }\end{array}$ & $\begin{array}{l}2.50 \\
2.66 \\
2.72 \\
2.75\end{array}$ & $\begin{array}{l}2.40 \\
2.40 \\
2.32 \\
2.10\end{array}$ \\
\hline $\begin{array}{l}{ }^{*} \mathrm{Bel} \text { o } \\
\text { ** In } \mathrm{t}\end{array}$ & 0 & sill & & & & & & & & \\
\hline
\end{tabular}




\section{SUMMARY}

The results of the tests and the rules for the design of the straight drop spillway stilling basin are summarized below. Reference should also be made to Fig. 10,

1. The minimum length of the stilling basin $I_{B}$ is

$$
I_{B}=x_{a}+x_{b}+x_{c}=x_{a}+2.55 d_{c}
$$

a. The distance from the headwall to the point where the surface of the upper nappe strikes the stilling basin floor $x_{a}$ is given by $\mathrm{Eq}$. (7). This equation is solved graphically in Fig. 2.

b. The distance from the point at which the surface of the upper nappe strikes the stilling basin floor to the upstream face of the floor blocks $x_{b}$ is

$$
x_{b}=0.8 d_{c}
$$

c. The distance between the upstream face of the floor blocks and the end of the stilling basin $x_{c}$ is

$$
x_{c} \geq 1.75 d_{c}
$$

2. The floor blocks are proportioned as follows:

a. The height of the floor blocks is

$$
0.8 \mathrm{~d}_{\mathrm{c}}
$$

b. The width and spacing of the floor blocks should be approximately

$$
0.4 d_{c}
$$

but a variation of $\pm 0.15 \mathrm{~d}_{c}$ from this limitis permissible.

c. The floor blocks should be square in plan.

d. The floor blocks should occupy between 50 and 60 per cent of the stilling basin width. 


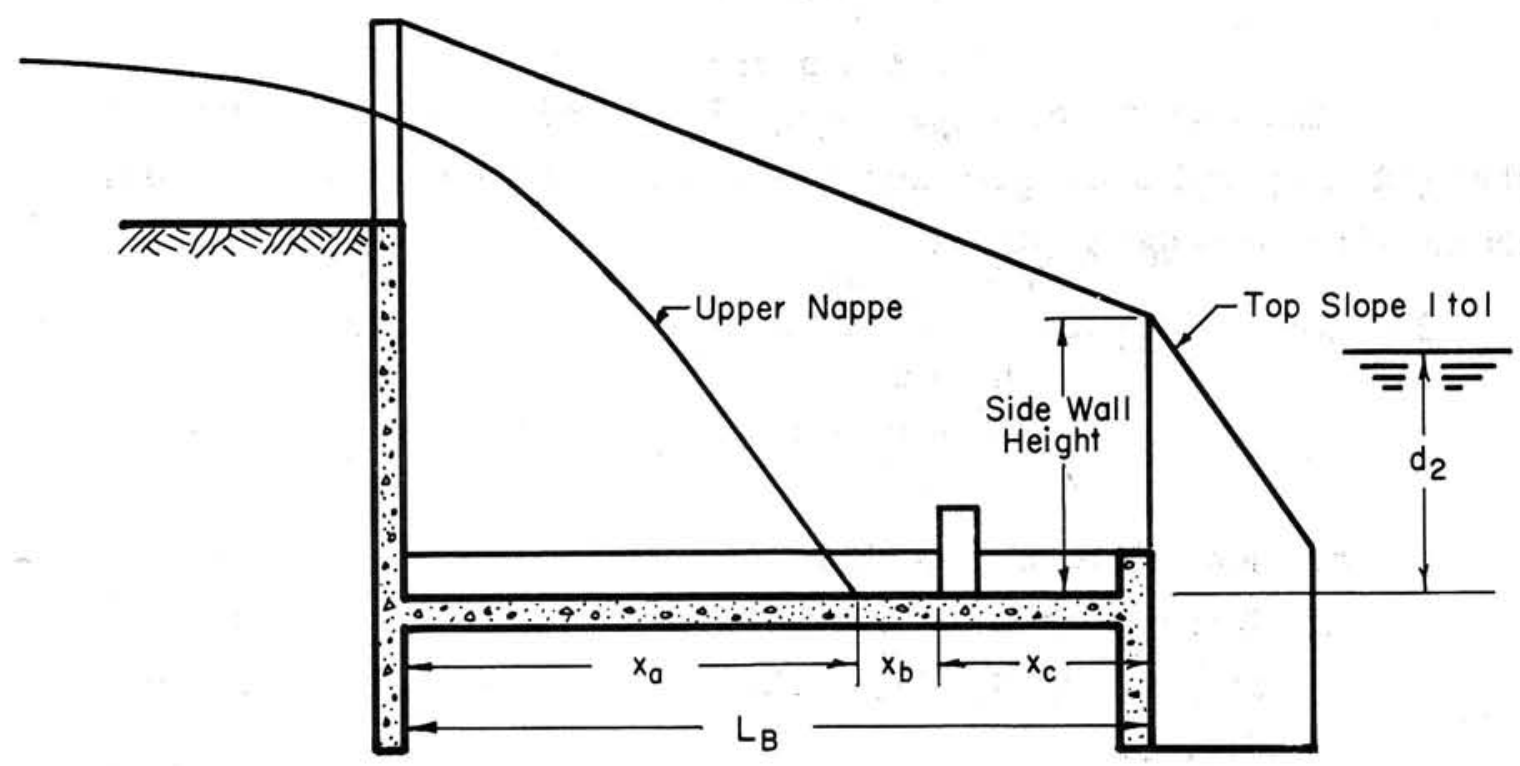

Section at Center Line

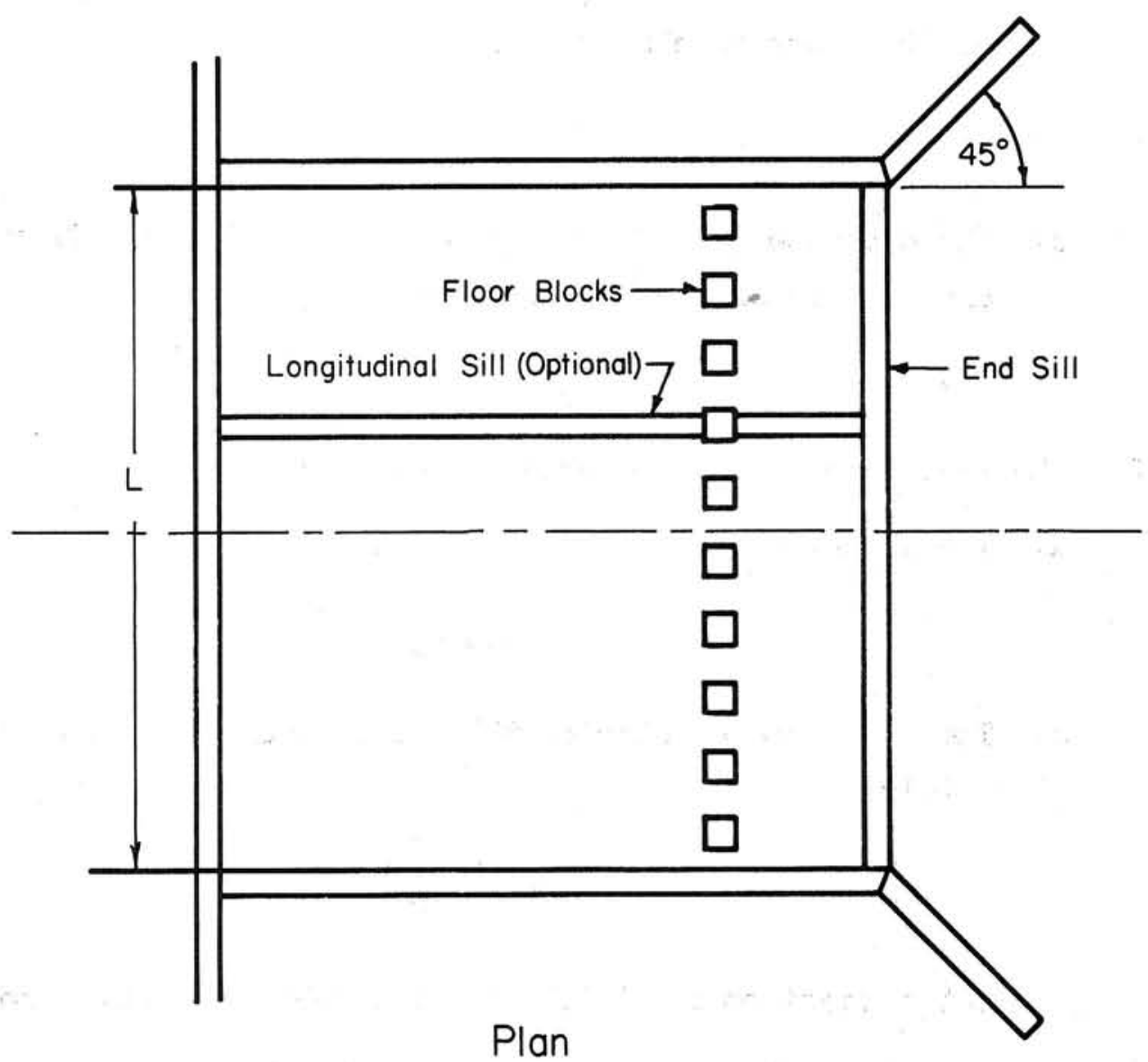

Fig. 10 - Straight Drop Spillway Stilling Basin 
3. The height of the end sill is

\section{Q.4 $d_{0}$}

4. Longitudinal sills may used for structural purposes. They are neither beneficial nor harmful hydraulically, If used, they should pass through, not between, the floor blocks.

5. The sidewall height above the tailwater level should be

$$
0.85 d_{c}
$$

6. The wingwalls should be located at an angle of $45^{\circ}$ with the outlet centerline and should have a top slope of $I$ on $I$.

7. The minimum height of the tailwater surface above the floor of the stilling basin $d_{2}$ is

$$
d_{2}=2,15 d_{c}
$$

8. The approach channel should:

a. Be level with the crest of the spillway.

b. Have the toe of the dike or the toe of the side slope intersect the approach channel floor at the ends of the spillway notch; the approach channel at the headwall should have a bottom width equal to that of the spillway notch.

c. Be protected by riprap or paving for a distance upstream from the headwall equal to two times the notch depth.

9. No special provision for aeration of the space beneath the nappe is required if the approach channel is shaped as recommended here.

\section{EXAMPIE OF APPLICATION}

An example is worked out here to show how the rules given in this paper are applied to the design of a stilling basin for a straight drop spillway. The selected exaruple is not necessarily typical but is chosen to bring out the application of the design rules.

The spillway design capacity is taken to be $330 \mathrm{cfs}$. The straight drop spillway is in a ditch with a $74.00-f t$ bottom width. The nomal depth of flow in the ditch is $4.00 \mathrm{ft}$, The total head $H$ above the spillway 
crest is assumed to be $4.00 \mathrm{ft}$, the velocity head being neglected in this case, ${ }^{*}$ for a crest length $L$ of $12.50 \mathrm{ft}$. The drop in the ditch grade whichmust be controlled is $6.00 \mathrm{ft}$. The nomal depth of flow in the downstream ditch is $4.00 \mathrm{ft}$, but under flood conditions backwater from a stream may raise the tailwater so that its level is $1.50 \mathrm{ft}$ above the spillway crest.

The drop from the spillway crest to the basin floor $y$ must first be determined. A knowledge of the tailwater depth is necessary to make this determination. The critical depth is taken as $d_{c}=(2 / 3) x$ $4.00=2.67 \mathrm{ft}$. The required tailwater depth is $2.15 \mathrm{~d}_{\mathrm{c}}$ above the stilling basin floor or $d_{2}=2.15 \times 2.67=5.73 \mathrm{ft}$. Nomal tailwater level is $2.00 \mathrm{ft}$ below the spillway crest so the stilling basin floor must be placed $-2.00-5.73=-7.73 \mathrm{ft}$ relative to (below) the spillway crest level. Therefore, $y=-7.73 \mathrm{ft}$ (use $-7.75 \mathrm{ft}$ ). The floor of the stilling basin is, therefore, $1.75 \mathrm{ft}$ below the grade line of the downstream channel.

The basin length $I_{B}$ will be determined next. The basin length computations are carried out in tabular form for both normal and flood ta.ilwater levels.

\section{Dimension}

\section{Tailwater}

\begin{tabular}{|c|c|c|c|}
\hline & & Normal & Flood \\
\hline $\mathrm{y}$ & ft & -7.75 & -7.75 \\
\hline$y / d_{c}$ & -- & -2.91 & -2.91 \\
\hline$y_{t}$ & ft & -2.00 & +1.50 \\
\hline $\mathrm{y}_{t} / \mathrm{d}_{\mathrm{c}}$ & - & -0.75 & +0.56 \\
\hline$x_{a} / d_{c}$ & - & 3.8 & 6.6 \\
\hline $\mathrm{x}_{\mathrm{a}}$ & ft & 10.13 & 17.60 \\
\hline$x_{b}=0.8 d_{c}$ & ft & 2.13 & 2.13 \\
\hline Distance to floor blocks & ft & $12.26(12.25)$ & $19.73(19.75)$ \\
\hline$x_{c}=1.75 d_{c}$ (minimum) & ft & $4.67(4.75)$ & $4.67(4.75)$ \\
\hline Basin length $I_{B}$ (minimum) & ft & $16.93(17.00)$ & $24.40(24.50)$ \\
\hline
\end{tabular}

*The velocity head is assumed to amount to $0.15 \mathrm{ft}$, and velocity head recovery at the headwall where the velocity is zero reduces the headwall freeboard by this amount. 
The principal controlling dimensions have been rounded off and the rounded values are given in parentheses. It will be noticed that the basin length is much longer for the high tailwater than for normal tailwater. The longer length naturally determines the required length of basin. The basin dimensions are shown in Fig. 11. The slope of the dam fill has been assumed to be 1 on 2 and has been dashed in to show its location. It will be noticed that the high tailwater requires a basin somewhat longer than is necessary to retain the fill. Minimum basin lengths are used and the dike has been shifted downstrean until its downstream toe intersects the wingwall at the elevation of the end sill.

If there had been only nomal tailwater depth in the downstream channel, the basin dimensions could have been those shown in Fig. 12. For this tailwater condition the computed basin length is so short that it does pot retain the fill. It is therefore necessary to lengthen the basin even though the dike has been shifted upstream as far as possible. To do this, the $x_{c}$ distance between the floor blocks and the end sill is increased from the minimum computed value of $4.75 \mathrm{ft}$ to a required $6.25 \mathrm{ft}$. In this case the fill governs the basin length rather than the hydraulic design criteria.

The minimum sidewall height above the tailwater level is 0.85 $d_{c}=0.85 \times 2.67=2.27$ (use 2.25) ft. This determines the height of the sidewall at the end of the basin and the length of the wingwall.

The end sill height is $0.4 d_{c}=0.4 \times 2.67=1.07$ (use 1.00) ft.

The height of the floor blocks is $0.8 \mathrm{~d}_{c}=0.8 \times 2.67=2.13$ (use 2.25) ft.

The floor block width and spacing should be approximately 0.4 $d_{c}=0.4 \times 2.67=1.07 \mathrm{ft}$, and they should occupy between $0.50 \times 12.5=$ $6.25 \mathrm{ft}$ and $0.60 \times 12.5=7.50 \mathrm{ft}$.

To fit the floor blocks into the basin width and keep within these limitations requires a number of trials and considerable juggling. However, if seven blocks $11-1 / 2 \mathrm{in}$. (0.96 ft) wide (the finished width of a 2 by 12 plank) are used, the width occupied by the blocks is $6 \mathrm{ft} 8-1 / 2$ inches. If the edge of the first block is located $4-3 / 4$ in. from the wall, the remaining blocks are spaced $10 \mathrm{in}$. apart. 

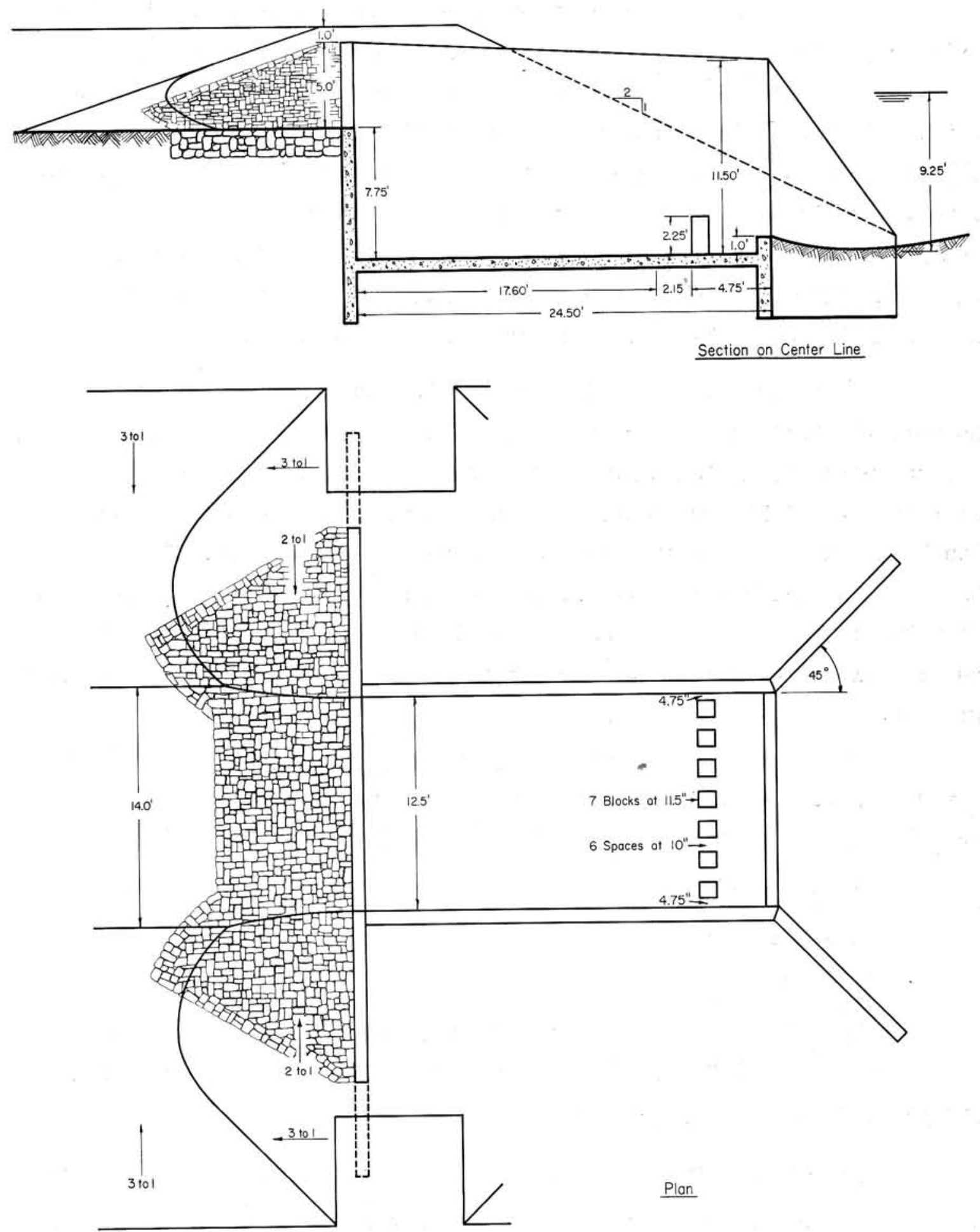

Fig. 11 - Example of Straight Drop Spillway Stilling Basin Designed for High Tailwater 

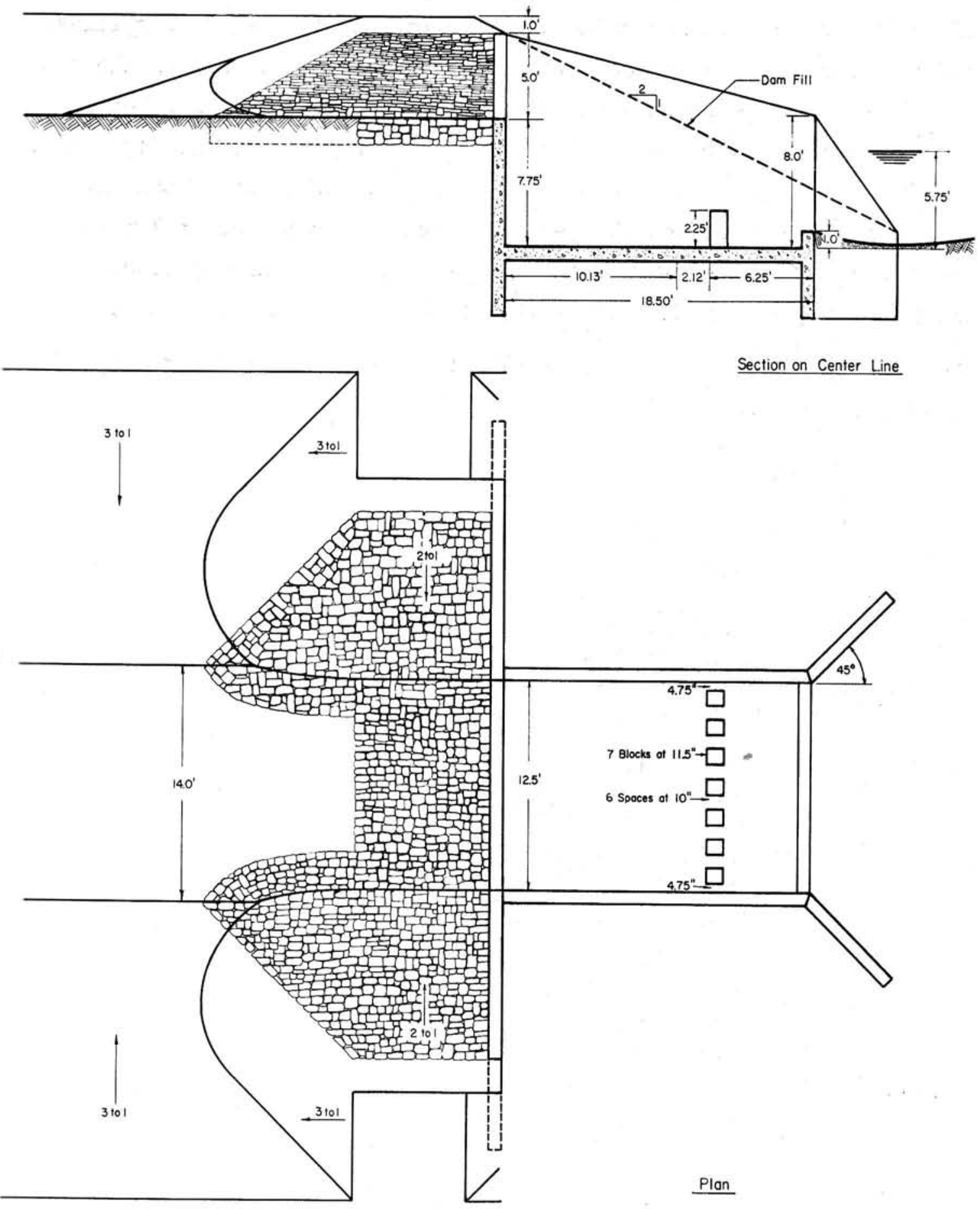

Fig. 12 - Example of Straight Drop Spillway Stilling Basin Designed for Normal Tailwater 
The approach channel is assumed to have a 14.0-ft bottom width and 1 on 3 side slopes. Since the notch is only $12-1 / 2$ ft long, there will have to be some narrowing of the ditch bottom near the spillway in order to have the side slopes intersect the crest at the ends of the notch. In addition, it is recommended that the side slopes at the headwall be 1 on 2. Therefore, a short dike will be used with an 8.0-ft top width, a $I$ on 2 end slope, and a 1 on 3 upstream slope. This use of the dike wall will also serve to reduce the required length of the headwall extension. The dike is installed as shown in Figs. 11 and 12. The approach channel close to the spillway is also riprapped to protect it from scour.

This completes the hydraulic design of the straight drop spillway stilling basin. 


\section{$\underline{B} \underline{I} \underline{B} \underline{L} \underline{I} \underline{O} \underline{G} \underline{R} \underline{A} \underline{P} \underline{H} \underline{Y}$}

[1] Morris, B. T. and Johnson, D. C. "Hydraulic Design of Drop Structures for Gully Control." Transactions of the American Society of Civil Engineers, Vol. 108, pp. 887-940. 1943.

[2] Blaisdell, Fred W. and Donnelly, Charles A. Hydraulic Model Studies for Whiting Field Naval Air Station. University of Minnesota, St. Anthony Falls Hydraulic Laboratory Project Report No. 23, January, 1950. 50 pages.

[3] Blaisdell, Fred W. "Development and Hydraulic Design, St. Anthony Falls Stilling Basin." Transactions of the American Society of Civil Engineers, Vol. 113, pp. 483-520. 1948.

[4] Blaisdell, Fred W. and Donnelly, Charles A. Hydraulic Design of the Box Inlet Drop Spillway. U. S. Department of Agriculture, Soil Conservation Service, SCS-TP-106, July 1951. 53 pages.

[5] Rouse, Hunter. Engineering Hydraulics. New York: John Wiley \& Sons, Inc., pp. 530-531, Fig. 12, 1950.

[6] Blaisdell, Fred W. "Equation of the Free-Falling Nappe." Proceedings of the American Society of Civil Engineers, Vol. 80, Separate No. 482, pp. 1-16. August, 1954.

[7] Ahmad, Nazir. "Mechanism of Erosion Below Hydraulic Works ." Proceedings of the Minnesota International Hydraulics Convention, University of Minnesota, St. Anthony Falls Hydraulic Laboratory, pp. 133-143. August, 1953.

[8] Donnelly, Charles A. Design of an Outlet for Box Inlet Drop Spillway. U. S. Department of Agriculture, Soil Conservation Service, SCS-TP-63, November, 1947. 31 pages.

[9] Hickox, G. H. "Aeration of Spillways." Transactions of the American Society of Civil Engineers, Vol. 109, pp. 537-566. 1944. 